Canadian

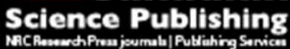

Applied Physiology, Nutrition, and Metabolism Physiologie appliquée, nutrition et métabolisme

\title{
Evidence for the essentiality of arachidonic and docosahexaenoic acid in the postnatal maternal and infant diet for the development of the infant's immune system early in life
}

\begin{tabular}{|r|l|}
\hline Journal: & Applied Physiology, Nutrition, and Metabolism \\
\hline Manuscript ID & apnm-2015-0660.R1 \\
\hline Manuscript Type: & Review \\
\hline Date Submitted by the Author: & $13-J a n-2016$ \\
\hline Complete List of Authors: & $\begin{array}{l}\text { Richard, Caroline; University of Alberta, Department of Agricultural Food } \\
\text { and Nutritional Science } \\
\text { Lewis, Erin; University of Alberta, Department of Agricultural Food and } \\
\text { Nutritional Science } \\
\text { Field, Catherine; University of Alberta, Department of Agricultural, Food } \\
\text { and Nutritional Science }\end{array}$ \\
\hline Keyword: & $\begin{array}{l}\text { cytokines < cytokines, diet < diet, growth < growth, nutrition < nutrition, } \\
\text { pediatrics < pediatrics }\end{array}$ \\
\hline &
\end{tabular}


TITLE:

Evidence for the essentiality of arachidonic and docosahexaenoic acid in the postnatal maternal and infant diet for the development of the infant's immune system early in life.

\section{AUTHORS:}

Caroline Richard, $\mathrm{PhD}, \mathrm{RD}^{1}$, Erin D. Lewis ${ }^{1}$, Catherine J. Field, $\mathrm{PhD}, \mathrm{RD}^{1}{ }^{1}$

${ }^{1}$ Department of Agricultural Food and Nutritional Science, University of Alberta, Edmonton, Alberta, Canada, T6G 2E1

Email addresses:

cr5@ualberta.ca

edlewis@ualberta.ca

${ }^{*}$ Corresponding author and request for reprints:

\section{Catherine Field}

Department of Agricultural, Food and Nutritional Science

4-126A Li Ka Shing Center for Health Research Innovation

University of Alberta, Edmonton, Alberta, Canada T6G 2E1

Phone: (780) 492-2597

Fax: (780) 492-2011

e-mail address: Catherine.field@ualberta.ca 


\begin{abstract}
Long chain polyunsaturated fatty acids (LCPUFA), especially the balance between the arachidonic (AA) and docosahexaenoic (DHA) acid are known to have important immunomodulatory roles during the postnatal period when the immune system is rapidly developing. AA and DHA are required in infant formula in many countries but are optional in North America. The rationale for adding these LCPUFA to full term formula is based on their presence in breast milk and randomized controlled studies that suggest improved cognitive function in preterm infants, but results are more variable in full term infants. Recently, the European Food Safety Authority has proposed, based on a lack of functional evidence, that AA is not required in infant formula for full term infants during the first year of life but DHA should remain mandatory. The purpose of this review is to review the evidence from epidemiological and intervention studies regarding the essentiality of AA and DHA in the postnatal infant and maternal diet (breast-feeding) for the immune system development early in life. Although studies support the essentiality of DHA for the immune system development, more research is needed in order to rule out the essentiality of AA. Nevertheless, intervention studies have demonstrated improvement in many markers of immune function in infants fed formula supplemented with AA and DHA compared to unsupplemented formula, which appears to consistently result in beneficial health outcomes including reduction in the risk of developing allergic and atopic disease early in life.
\end{abstract}

\title{
KEY WORDS:
}

Nutritional immunology, postnatal diets, early development, arachidonic acid, docosahexaenoic acid, allergy, atopic diseases, infant formula, breast milk 


\section{1-Background}

Linoleic acid (LA) and linolenic acid (ALA) are essential fatty acids of the omega-6 (n-6) and n-3 family, respectively, that must be obtained from the diet. These fatty acids can be metabolized to some extent to the metabolically essential long chain polyunsaturated fatty acids (LCPUFAs), arachidonic (AA), eicosapentaenoic (EPA) and docosahexaenoic (DHA) acid. LCPUFA, in particular AA and DHA, have been shown to be important for cognitive and visual development in infant (reviewed by (Gould et al. 2013; Janssen and Kiliaan 2014). In a study examining breast milk composition of over 30 countries worldwide from North America, Southeast Asia, South Asia, Europe and Africa, average DHA and AA concentrations were $0.32 \pm 0.22 \%$ and $0.47 \pm 0.13 \%$, respectively (Brenna et al. 2007). Whether these fatty acids are required in the maternal diet remain to be established, but studies revealed that DHA breast milk composition varies to a greater extent than AA concentrations, and appears to be more dependent on dietary intake (Yuhas et al. 2006; Brenna et al. 2007). Although AA and DHA constitute less than $1 \%$ of the total fatty acids in breast milk, there is evidence that the supply of LCPUFA are important for the development of the immune system in the infant (reviewed by (Field et al. 2001; Calder et al. 2006; Calder et al. 2010)). Indeed, there are some promising results from studies demonstrating that high intakes (through diet or supplements) of n-3 LCPUFA during pregnancy by women with a history of atopic disease, can reduce the risk and symptoms of asthma (Dunstan et al. 2003; Peat et al. 2004; Salam et al. 2005; Romieu et al. 2007; Gunaratne et al. 2015) and allergies (Dunstan et al. 2003; Mihrshahi et al. 2003) in their infants (reviewed by (Blumer and Renz 2007; Kremmyda et al. 2011)). LCPUFA supplementation in the postnatal period has also been reported to have beneficial effects on the appearance of atopic symptoms both in infants with a family history of atopic diseases (Damsgaard et al. 2007; Hwang et al. 2007) and without (Birch et al. 2010). This epidemiological evidence supports the importance of LCPUFA early in life for immune development. 
Despite being present in breast milk, the importance of providing AA and DHA in the diet of full term infants has been widely debated (Crawford et al. 2015; Koletzko et al. 2015; Lauritzen et al. 2015). The assumption is full term infants are able to synthesize sufficient amounts from the 18C dietary precursors, however this may be incorrect as insufficient conversion to AA and DHA has been reported in infants (Pawlosky et al. 2006; Carnielli et al. 2007). Various organizations including the Child Health Foundation (CHF), Health Council of the Netherlands, Food and Agriculture Organization of the United Nations (FAO) have recommended addition of AA and DHA to infant formula. The rationale for requiring the addition of these LCPUFA to full term infant formula (FAO/WHO 1994; Simopoulos et al. 2000; Koletzko et al. 2001; Health Council of The Netherlands, 2001) is based both on their presence in breast milk (a gold standard for infant nutrition) and randomized controlled studies (RCT) that suggest improvements in neurocognitive and visual function, particularly for preterm infants (Simmer 2000a; Simmer 2000b; Uauy et al. 2001). However, in 1998, the American Life Sciences Research Office (LSRO) did not recommend requirements for AA and DHA in infant formula until more results of RCT became available, thus both supplemented and unsupplemented formulas are available in North America. Recently, the European Food Safety Authority (EFSA) has proposed, based on a lack of functional evidence, that AA is not required in infant formula for full term infants during the first year of life, but DHA should remain mandatory. The majority of evidence cited focused on the impact on growth and cognitive development but the postnatal period is also important for immune system development and these two fatty acids have a significant effect on immune function (reviewed by (Harbige 2003)).

The infant is born with an immune system that is very different from an adult and the early postnatal period is a critical stage where many immune functions are acquired. Although the innate immune system tends to function quite well in an infant, the adaptive immune system is relatively naïve at birth 
due to low antigen exposure in utero, and lacks the immunological memory and functionality of the adult (Perez-Cano et al. 2012). In the postnatal period, immune system development and function is influenced by diet (breast milk and foods) and the internal (microbiome) and external (pathogens and contaminants) environments (Blumer et al. 2007). An important T cell mediated process that occurs early in life is the development of oral tolerance, referring to the ability to distinguish between harmful and harmless antigens delivered via the oral route (Garside and Mowat 2001). Food allergies are believed to be the result of a failure to develop oral tolerance to a dietary antigen. Another key player in allergic reactions are B cells, which have the ability to produce antigen specific antibodies (immunoglobulins, Ig), known as humoral immunity. The expression of Ig on B cells occurs in various stages of development, with only IgG being transferrable from maternal blood across the placenta. Breast milk is a major source of IgA and believed to protect the infant and have a beneficial effect on immune function in breast fed infants, during this early postnatal period when the immune system is developing (M'Rabet et al. 2008). At birth, T cells have a lower ability to respond to immune challenges (i.e. proteins, pathogens, toxins) and when they respond they favor a type $2 \mathrm{~T}$ helper (Th2) cytokine response (interleukin (IL)-4, IL-5, IL-10 and IL-13) that promotes a humoral response to extracellular pathogens over a Th1 response (Prescott 2003). The production of Th1 cytokines, including interferon-gamma (IFN- $\gamma$ ), IL-2 and tumor necrosis factor-alpha (TNF- $\alpha$ ), has been demonstrated to gradually increase during the suckling period in rodents or the first year of life in infants (Albers et al. 2005; Hartel et al. 2005). Compared to adults, neonatal T cells require more costimulation in order to mount an efficient Th1 response, both in vivo and ex vivo (Adkins et al. 2001). It is proposed that during this period of immune system 'immaturity', the infant is more vulnerable to challenges from their environment (Calder et al. 2010). It is also hypothesized that the inappropriate Th2 response increases the risk for allergic diseases and asthma (Prescott 2003). 
The purpose of this review is to review the evidence from epidemiological and intervention studies regarding the essentiality of AA and DHA for the immune system development early in life. Specifically, this review will 1) review the evidence from epidemiological studies assessing the association between AA and DHA breast milk composition and the early immune system development; 2) review the evidence for the essentiality of AA and DHA in the postnatal infant diet for immune system development early in life; and 3) review the evidence for DHA supplementation in the postnatal maternal diet (breast-feeding) and the impact on the infant's immune system development early in life. When assessing the immune system development, we can assess markers of the immune function (cytokines, immunoglobulin) and health outcome such as the risk of developing allergy/atopic diseases. Most studies so far have assessed the impact of LCPUFA in high risk children born from mothers with atopic diseases, therefore the majority of studies mentioned in this review examine the development of the immune system, within the context of allergy and asthma development. The methods of the review and the data extractions details are presented in a Supplementary File.

\section{2- Association between AA and DHA breast milk composition and the immune system development: Evidence from epidemiological cohort studies}

Epidemiological data suggest that infants who are not exclusively breast-fed are at higher risk of developing atopic diseases (van Odijk et al. 2003), which is the predisposition towards developing certain allergic hypersensitivity reactions, thereby implicating a role of early diet in the process of developing tolerance. The increased incidence of asthma, hayfever, atopic eczema, food allergy and other related allergic syndromes (collectively called atopic diseases) is often associated with a high intake of LA, coupled with a low intake of EPA and DHA in the 'Western type' diet (Dunstan and Prescott 2005). The relationship between intake of LCPUFA and immune system development has focused on atopy. This topic has been discussed in the scientific literature for many decades, however research has focused primarily on the perinatal period. The systematic literature search first retrieved 
39 articles of which all title and abstract have been screened. Of these, 27 articles did not meet the inclusion criteria and 12 full text articles were assessed. A total of six prospective studies were identified and included in the review examining the association between LCPUFA breast milk composition or infant diet and the development of immune system in infants or children, specifically assessing the development of atopic diseases. The remaining six studies did not contain results on the outcomes of interest. A summary of the six epidemiological studies included in the present review is provided in Table 1. Three of the six studies assessed clinical symptoms of atopic disease and four studies used skin prick tests (SPT) to assess presence of an atopic disease. The children's ages in the epidemiological studies ranged from three months to four years. Four of the six studies included only women and their children with a family history of atopic disease. Two case-control studies compared women and child pairs with a family history of atopic disease to women-child pairs with no history of atopic disease.

An early study conducted by Wright and Bolton (1989) found that the relative proportion of LA (12.8\% $\pm 3.6 \%$ vs. $10.2 \% \pm 3.4 \%$ ) was higher in breast milk of mothers who had infants that presented with clinical symptoms of atopic eczema at 2 to 6 months of age, compared to a control group of infants without atopic eczema. The relative proportion of AA $(0.8 \% \pm 0.3 \%$ vs. $1.0 \% \pm 0.5 \%)$ was lower in the breast milk of mothers with atopic children, but this did not reach significance. The relative proportion of EPA or DHA in breast milk was not significantly different between the atopic and control group (Wright and Bolton 1989). In a more recent study, Duchen et al. (2000) found that the relative proportion of DHA $(0.19 \% \pm 0.09 \%$ vs. $0.25 \% \pm 0.16 \%)$ in breast milk from mothers at 3 months postpartum with infants who developed symptoms of atopic diseases at 18 months was lower compared to non-atopic infants (Duchen et al. 2000). A similar observation was made by Oddy et al. (2006), reporting a higher total n-6/n-3 ratio in breast milk from mothers at 6 weeks of age with infants who developed non-atopic eczema at 6 months of age (Oddy et al. 2006). This higher total n-6/n-3 ratio was 
due to a lower percentage of total n-3 (2.12\% vs. 2.44\% in breast milk from mothers with infants with no atopy or eczema) and higher percentage of total n-6 (14.6\% vs. $12.8 \%$ total n- 6 in breast milk from mothers with infants with no atopy or eczema) in non-atopic eczema infants (Oddy et al. 2006). In a case-control cohort, there was a significant difference in breast milk content of DHA $(0.2 \% \pm 0.10 \%$ vs. $0.3 \% \pm 0.06 \%$ ) from mothers whose infants were diagnosed with atopic dermatitis at 3-6 months of age compared to infants with no atopic dermatitis, or a family history of atopic diseases (Businco et al. 1993). In this study there was no significant difference in AA content in breast milk from mothers with allergic and non-allergic infants $(0.5 \% \pm 0.1 \%$ vs $0.6 \% \pm 0.14 \%)$ (Buscino et al. 1993). In the Prevention and Incidence of Asthma and Mite Allergy (PIAMA) prospective birth cohort, breast milk concentrations of AA from the early lactation period (63-184 days post-delivery) were not significantly different between mothers with children with allergy $(0.36 \%)$ and mothers with children without allergy $(0.39 \%)$. Similarly, breast milk concentrations of DHA were not significantly different between mothers with allergic $(0.17 \%)$ and non-allergic children $(0.16 \%)$. There was an inverse association observed between breast milk DHA content and asthma in children at 4 years of age $(\mathrm{OR}=0.39[95 \%$ IC: $0.16-0.99])$, however this association was only observed in children from mothers who had a history of allergy (Wijga et al. 2006). Lowe et al. (2008) also reported an association between fatty acid breast milk content and risk of allergic disease (non-atopic eczema, OR=1.60 [95\% IC: 1.03-2.50]). However, this association was not due to DHA (0.07-1.17) or EPA (0.0-0.29) but due to higher concentration of the precursor fatty acid ALA (0.42-2.32) (Lowe et al. 2008). Epidemiological studies examining the postnatal period and the association between breast milk LCPUFA content and the development of atopic diseases in children suggest that low DHA content may increase the risk of atopic disease in infants, yet studies are conflicting on the role of AA. It also appears that the ratio of total n-6/n-3 may be important for the risk of atopic diseases in children. One consideration is that the majority of studies have only studied women and children where there is a family history of atopic 
disease. Therefore these studies do not provide information on the importance of these fatty acids in 'normal' immune development in the postnatal period.

\section{3-Impact of AA and DHA in the postnatal infant's diet on immune system and oral tolerance development}

The systematic literature search first retrieved 39 articles for which titles and abstracts were screened. Of these, 25 articles did not meet the inclusion criteria and 14 full text articles were assessed. A total of nine research articles reporting the results of six nutritional intervention trials were identified and included in the review that studied the impact of LCPUFA in the postnatal infant's diet on immune system development. A summary of the nine nutritional intervention studies included in the present review is provided in Table 2. Seven of the nine trials were randomized double blind controlled trials and two were prospective observational open label studies, of which two provided a daily fish oil supplement (110 mg EPA and $280 \mathrm{mg}$ DHA) to infants and seven provided infant formula enriched or not in AA (range $0.34-0.72 \%$ ) and DHA (range $0.2-0.36 \%$ ). The duration of the interventions varied from 4 weeks (1 month) to 12 months and two studies included infants at high risk of atopic diseases. Two published studies came from the same group in Australia (D'Vaz et al. 2012a; D'Vaz et al. 2012b), one in France (Lapillonne et al. 2014), one in Spain (Pastor et al. 2006), one in the United States (Dallas) (Birch et al. 2010) and four studies from the same group in Canada (Field et al. 2000; Field et al. 2008a; Field et al. 2008b; Field et al. 2010). Of the nine trials, markers of immune function or incidence of allergic and atopic diseases was the primary outcome of five trials, the secondary outcome of two trials and this information was unspecified for two articles.

Two nutritional intervention studies from the same group; one in preterm (Field et al. 2000) and one in term infants (Field et al. 2008a; Field et al. 2008b; Field et al. 2010) studied the impact of feeding formula supplemented with AA and DHA on markers of immune system development. In these 
randomized double-blinded studies, preterm and term infants at low risk of allergic diseases were fed infant formula enriched or not in AA and DHA and compared to a control group of infants fed human milk (considered the ideal food source for infants). A significant portion of immune development occurs during the third trimester of pregnancy (Holt and Jones 2000), which would result in preterm infants having an even less mature immune system than an infant born at term. Adding AA and DHA ( $0.49 \%$ AA and $0.35 \%$ DHA of total fatty acids) to preterm infant formula assisted in the maturation of $\mathrm{T}$ cells, particularly CD4+ $\mathrm{T}$ cells expressing the antigen mature marker $(\mathrm{CD} 45 \mathrm{RO}+)$, comparable to proportions from breast-fed infants (Field et al. 2000). Feeding infant formula supplemented with AA and DHA to preterm infants for 4 weeks also improved the ability of immune cells to produce IL-10 after PHA (a T cell mitogen) stimulation, a cytokine associated with $\mathrm{T}$ cell maturation and the development of oral tolerance (Field et al. 2000). Animal studies have also provided support that LCPUFA in the postnatal period may assist in immune development. Piglets (a human infant model) fed a formula supplemented with AA and DHA, compared to unsupplemented formula, had higher IL10 mRNA expression in lymphocytes (after immunization) that was similar to lymphocytes from piglets fed sow's milk during the first 30 days of life (Bassaganya-Riera et al. 2007). This suggests that providing AA and DHA in the infant diet after birth is important in supporting $\mathrm{T}$ cell development.

In infants delivered at term, feeding infant formula supplemented in AA and DHA $(0.34 \%$ AA and $0.2 \%$ DHA of total fatty acids) led to an immune cell distribution and cytokine profile that was more similar to that of the exclusively breast-fed infants (Field et al. 2008a). However, infants fed formula (enriched in LCPUFA or not) had a higher Th1 response (higher IFN- $\gamma$ production after T cells stimulation) compared to infant that were exclusively breast-fed. IFN- $\gamma$ is a key immunoregulatory cytokine thought to facilitate the development of oral tolerance (Sutas et al. 1997). Cord blood cells from infants at low risk for allergy were found to produce a significantly higher amount of IFN- $\gamma$ than 
cells from a high-risk group (Osterlund and Suomalainen 2002). It is hypothesized that the production of this cytokine would be necessary to create tolerance in formula-fed infants, who are not receiving IFN- $\gamma$ from breast milk. Consistent with this hypothesis, immune cells from infants that received the supplemented formula also produced more IFN- $\gamma$ after exposure to $\beta$-lactoglobulin, a potential dietary antigen (Field et al. 2008b; Field et al. 2010). It was also reported that the cells from the LCPUFA supplemented infants produced more TNF- $\alpha$ when incubated with soy protein, another dietary antigen. TNF- $\alpha$ might assist in the differentiation of dendritic cells (Tang et al. 1993) which could reduce the allergic response. Overall, these changes observed by adding AA and DHA to infant formula promoted the response of the infant's immune system towards a response that is more similar to exclusively breast-fed infants. Human milk is a complex mixture of compounds with immune modulating properties (Hosea Blewett et al. 2008) and these studies support the hypothesis that providing AA, as well as DHA, in infant formula may be important in promoting the maturation of the immune system.

In an open (non-randomized) trial in Spain, feeding infant formula supplemented with AA and DHA (34 mg AA and $17 \mathrm{mg}$ DHA), compared to unsupplemented formula, resulted in a lower incidence of bronchitis during the first year of life (Pastor et al. 2006). This observation was confirmed in a randomized double-blinded controlled trial in the US, where infants that were fed formula supplemented with AA and DHA (0.64-0.72\% AA and 0.32-0.36\% DHA of total fatty acids) for 12 months had a lower incidence of upper respiratory infections or any allergy (comprising wheezing, asthma, atopic diseases, allergic rhinitis or conjunctivitis, food allergy and urticarial) at 3 years of age (Birch et al. 2010). Lapillonne et al. (2014) showed in their observational prospective open label study conducted in France that feeding infant formula enriched in LCPUFA (AA and DHA, 34 mg AA and 17 mg DHA) for 12 months resulted in a lower incidence of bronchitis, croup, nasal congestion, cough and diarrhea that required medical attention compared to a historical control (Lapillonne et al. 2014). 
D'Vaz et al. (2012b) conducted a randomized double-blinded placebo controlled study where term infants at high risk of atopic diseases received a daily supplement of fish oil (110 mg EPA and $280 \mathrm{mg}$ DHA) or a placebo (olive oil) from birth to 6 months of age. They reported several improvements in markers of immune function with fish oil supplementation during the first 6 months of life (Table 2) (D'Vaz et al. 2012a). Among them, there was a suggested lower allergic response (lower production of IL-13) to house dust mite (HDM) and a higher Th1 response (IFN- $\gamma$ and TNF- $\alpha$ ) after $\mathrm{T}$ cell stimulation in the fish oil group compared to the placebo (D'Vaz et al. 2012a), indicative of enhanced immune maturation. However, the intervention did not result in a lower prevalence of allergic and atopic diseases (i.e. any allergic diseases, sensitization and eczema) nor recurrent wheeze or persistent coughing at 12 months. Nevertheless, supplementing infants with fish oil early in life might have a modest beneficial effect as plasma DHA concentration at 6 months was negatively associated with the incidence of recurrent wheeze in the first 12 months of life (D'Vaz et al. 2012b). In summary, the only study so far that provided a fish oil (EPA and DHA) supplement to infants failed to demonstrate a beneficial effect on health outcomes, yet studies evaluating the impact of infant formula enriched in AA and DHA (from 0.34 to $0.72 \% \mathrm{AA}$ and from 0.2 to $0.36 \% \mathrm{DHA}$ ) consistently reported a lower incidence of infections or allergic and atopic diseases early in life.

\section{4-Impact of fish oil (EPA and DHA) supplementation in the postnatal maternal diet (breast- feeding) on immune system and oral tolerance development}

The systematic literature search first retrieved 56 articles of which all title and abstract have been screened. Of these, 44 article did not meet the inclusion criteria and 12 full text articles were assessed. A total of six research articles reporting the results of three nutritional intervention trials were identified and included in the review regarding the impact of DHA, usually provided as fish oil supplementation, in the postnatal maternal diet on immune system development. A summary of the six 
nutritional intervention studies included in the present review is provided in Table 3. Only three nutritional intervention studies were performed during the lactation period. We decided to include one study, for which three research articles have been published, that started the nutritional intervention during the third trimester of pregnancy, but excluded other studies that started earlier in pregnancy (Granot et al. 2011). All selected studies were RCT in which a daily fish oil supplement containing EPA (range: $195-1600 \mathrm{mg} / \mathrm{d}$ ) and DHA (900-1100mg/d) was provided to lactating women. The duration of the interventions varied from 9.4 weeks (2.2 month) to 4 months postpartum. One study, from which two articles were published, was performed in preterm infant. Two published studies from the same group were from Australia (Manley et al. 2011; Atwell et al. 2013), one in Denmark (Lauritzen et al. 2005) and three studies from the same group were done in Sweden (Furuhjelm et al. 2009; Furuhjelm et al. 2011a; Furuhjelm et al. 2011b). Four of the trials included markers of immune function or incidence of allergic and atopic diseases as the primary outcome, and the secondary outcome for the remaining two trials.

The DINO trial supplemented lactating women with preterm infants with a daily fish oil supplement (195 mg of EPA and $900 \mathrm{mg}$ of DHA) or a control supplement containing soy oil from birth until the expected delivery date (median duration of 9.4 weeks) and reported the incidence of allergic and atopic diseases as a secondary outcome. There was a reduction in parental reports of hay fever in breast-fed infants from fish oil supplemented mothers at 12 and 18 months (corrected age) (Manley et al. 2011). However, no difference in any other allergy and respiratory outcomes, or the proportion of infants hospitalized for lower respiratory tract conditions was observed in the first 18 months of life between groups (Manley et al. 2011; Atwell et al. 2013). Although the incidence of allergic and atopic diseases was not the primary outcome of the DINO study, this is an important study regarding the impact of supplementing the maternal diet in n-3 LCPUFA on breast milk composition. This is the only study 
that supplemented the maternal diet with DHA in order to achieve a breast milk composition of $1 \%$ DHA, without changing the amount of AA.

Lauritzen et al. (2005) designed the only study assessing the impact of fish oil supplementation strictly in the postnatal maternal diet on immune system development early in life as a primary outcome (Lauritzen et al. 2005). In this study, women consumed a daily fish oil supplement containing $390 \mathrm{mg}$ of EPA and $900 \mathrm{mg}$ of DHA or an equivalent daily control supplement containing olive oil during the first 4 months of lactation. Fish oil supplementation resulted in significantly higher EPA and DHA concentrations in infants' erythrocytes at 4 months without changing the AA content (Lauritzen et al. 2004). These changes in the fatty acid composition of erythrocytes were associated with a higher Th1 response (higher IFN- $\gamma$ production) later in life (Lauritzen et al. 2005). Despite indication of a benefit to immune development, at 2.5 years there was no difference in plasma IgE concentrations and the percentage of children diagnosed with atopic diseases (eczema or food allergy) between groups. This was the first study to demonstrate, as a primary outcome, that fish oil supplementation in the maternal diet, strictly during the postnatal period, has a positive programming effect on immune system development later in life.

Our group, recently established a rodent model to study the effect of DHA supplementation during the suckling period (first 21 days of life in rodents). Consistent with the DINO trial, we demonstrated that adding a small amount of DHA $(0.9 \% \mathrm{w} / \mathrm{w}$ of fat $)$ into an essential fatty acid sufficient AA supplemented $(0.4 \% \mathrm{w} / \mathrm{w}$ of fat) maternal diet, increased the content of DHA in breast milk (measured as stomach content) from $0.24 \% \mathrm{w} / \mathrm{w}$ to $1.1 \% \mathrm{w} / \mathrm{w}$ of fat, while also increasing the content of AA from $0.44 \% \mathrm{w} / \mathrm{w}$ to $0.69 \% \mathrm{w} / \mathrm{w}$ of fat compared with the control diet $(0.4 \% \mathrm{AA}$ and $0 \% \mathrm{DHA} \mathrm{w} / \mathrm{w}$ of fat $)$ (Richard et al. 2015). Changes in the fatty acid composition of immune cell membranes have been suggested to be the mechanism for the effect of LCPUFA in the diet (Calder 2008). Consistent with this 
hypothesis and the findings by Lauritzen et al (2004) in their clinical trial, feeding a maternal diet with $\mathrm{DHA}+\mathrm{AA}$, resulted in a higher proportion of DHA in splenocyte phospholipids, without changing the AA composition. We found indications of improved immune and tolerance development in the offspring from the DHA+AA supplemented dams (more activated B cells isolated from the spleen and a lower production of TGF- $\beta$ when splenocytes were challenged with ovalbumin (a common food antigen)) (Richard et al. 2015). These results were confirmed in a subsequent study in which pups were orally sensitized to the dietary antigen ovalbumin prior to the end of suckling. Offspring from the $\mathrm{DHA}+\mathrm{AA}$ supplemented moms produced more IL-10 and less TGF- $\beta$, suggestive of better oral tolerance (unpublished results). In the same study, feeding DHA during suckling also improved the ability of immune cells to respond to both a $\mathrm{T}$ cell mitogen (Concanavalin A (Con A)) and a bacterial antigen (lipopolysaccharide (LPS)), by producing more IFN- $\gamma$ and TNF- $\alpha$, respectively. Overall, these results suggest that feeding a maternal diet enriched in DHA during the suckling period, while providing a sufficient amount of AA, beneficially affects immune maturation toward an improved Th1 response, which may have a favorable effect on the establishment of oral tolerance early in life.

One randomized double blind placebo controlled trial assessed the impact of fish oil supplementation (1600 mg EPA and $1100 \mathrm{mg}$ DHA per day) in the maternal diet from the third trimester of pregnancy to 3.5 months postpartum in breast-fed infants at high risk of developing allergy on markers of immune function and the incidence of allergy during the first 2 years of life (Furuhjelm et al. 2009). This group found a lower risk of developing food allergy (a positive SPT to egg) and eczema (IgE-associated eczema) in infants at 12 months of age, from mothers who received a fish oil supplement compared with the placebo group. They further showed that infants in the fish oil group had a lower cumulative incidence of markers of atopic disease (positive SPT to food and IgE-mediated food reactions and IgEassociated eczema) during the first 2 years of life compared with the placebo group (Furuhjelm et al. 2011b). A higher proportion of EPA and DHA in maternal plasma phospholipids at one week after 
delivery was associated with a lower cumulative incidence of IgE-associated diseases in infants in this study, suggesting that maternal status during pregnancy may have contributed to their results. A dysregulation in the $\mathrm{Th} 1 / \mathrm{Th} 2$ response has been proposed to be one of the mechanisms involved in development of allergic and atopic diseases (Prescott and Dunstan 2007). They reported that maternal fish oil supplementation differentially affected the Th1 response in infants according to their allergic status (i.e. different response in infant with and without a maternal history of allergy) (Furuhjelm et al. 2011a). This suggests that the impact of maternal DHA supplementation on the development of the immune system and the establishment of oral tolerance may differ based on the family history of allergic and atopic diseases, which is an important consideration in future research.

\section{5-Impact of AA or DHA alone in the postnatal diet on immune system and oral tolerance development}

There is currently no study that has assessed the impact of AA or DHA supplementation separately during the postnatal period either through the maternal or the infant's diet. AA has always been provided in combination with DHA in infant formula, and DHA with EPA since all studies used fish oil supplementation as a way to deliver DHA. One study reported a potential beneficial effect of n-6 LA supplementation, a precursor for AA synthesis, during pregnancy and lactation on the prevalence of atopic dermatitis (Linnamaa et al. 2010). In this study, pregnant women consumed a daily blackcurrant seed oil supplement (composed mainly of n-6 LA (48\%) and n-3 ALA (14\%)) or a placebo (olive oil) from the first trimester of pregnancy until cessation of breastfeeding, and then infants were supplemented until 2 years of age. They reported a lower prevalence of atopic dermatitis and improvement in the SCORAD index (used to assess the severity of atopic symptoms) in infants that received the blackcurrant seed oil supplement at 12 months of age (Linnamaa et al. 2010). However, the experimental diet also contained a significant amount of n-3 and no information was reported regarding the maternal and infant's AA status during the intervention. Future studies clearly need to 
address the question of the essentiality of AA independent of DHA before any conclusion can be drawn.

Although the importance of adding adequate amounts of AA to infant formula is currently under debate (Crawford et al. 2015; Delplanque et al. 2015; Koletzko et al. 2015; Lauritzen et al. 2015), there are reasons to believe that an exogenous supply of AA in the early postnatal period is essential for the immune system. Indeed, there is a rapid increase in the content of AA in the thymus in the early postnatal period (Calder 2008), the most important period of T cell and tolerance development (Garside and Mowat 2001). Furthermore, it has been shown in humans and in rodents that feeding diets with a low n-6/n-3 LCPUFA ratio increases the content of n-3 and decreases the content of n-6 (particularly AA) in cell membrane phospholipids (Fritsche 2007; Calder 2008). To date, most studies using n-3 supplementation have provided very high doses of n-3 LCPUFA, without adding AA in the diet. This in turn lowers the n-6/n-3 LCPUFA ratio of the diet, leading to overall anti-inflammatory and immunosuppressive effects (primarily by reducing cell content of AA) (Sasaki et al. 1999; Zeyda et al. 2002; Fan et al. 2004; Calder 2008; Kim et al. 2010). While these effects are expected to be beneficial in adults with chronic low-grade inflammation (Calder 2008), it is likely undesirable in the early postnatal period where the immune system is rapidly developing and acquiring many essential functions. Therefore, maintaining an adequate balance between n-6 and n-3 LCPUFA intake is important early in life for an optimal immune system development. Considering that the maternal diet seems to have little impact on the AA content of breast milk (Yuhas et al. 2006; Brenna et al. 2007), the concern about breast-fed infants not receiving enough AA might be of less importance. However, providing a sufficient amount of AA appears to be essential in the early postnatal diet of non-breast fed infants, at least when combined with DHA, since studies assessing the impact of infant formula supplemented in AA and DHA consistently report a beneficial effect on the development of atopic and allergic diseases, as previously discussed. 


\section{6-Conclusions and future directions}

Epidemiological studies suggest an inverse association between breast milk DHA content and the development of atopic disease in children with family history of atopic disease. Evidence from nutritional intervention studies suggest that supplementing the maternal diet with fish oil (during late pregnancy and/or lactation) and feeding infant formula enriched in AA and DHA alters markers of immune function in a direction that is thought to be beneficial and promote establishment of oral tolerance in the first year of life. Although studies support the essentiality of DHA for the development of the immune system, more research is needed before one can rule out the essentiality of dietary AA in the diet of infants in the first year of life. Indeed, no study so far has examined the impact of either AA (independent from DHA) or DHA (independent from EPA) alone and based on their presence in the maternal diet (albeit in low amounts) and breast milk, as conducting these studies may not be possible for ethical reasons. Additionally there is concern that breast milk might not be providing the optimal intake of these fatty acids with the 'Westernization' of mothers' diets being too high in n-6 LA and too low in n-3 LCPUFA. Finally, little is known about the AA and DHA content of the diet during the transition from breast milk to the adult diet during the first few years of life when the immune system is still developing. Nevertheless, considering that no adverse effects have been reported with infant formula enriched in AA and DHA and that studies have demonstrated improvements in many markers of immune function that appear to consistently result in health beneficial effects, infant formula supplemented in AA and DHA should be recommended to ensure 'optimal' immune development and function.

\section{Abbreviations used:}

AA, arachidonic acid; ALA, $\alpha$-linolenic acid; ConA, Concanavalin A; DHA, docosahexaenoic acid; DPA, docosapentaenoic acid; IFN- $\gamma$, interferon-gamma; IL, interleukin; LPS, lipopolysaccharide; 
MUFA, monounsaturated fatty acid; n, omega; OVA, ovalbumin; PUFA, polyunsaturated fatty acid; SFA, saturated fatty acid; TGF- $\beta$, transforming growth factor-beta; TNF- $\alpha$, tumor necrosis factoralpha;

Disclosures: Authors report no conflict of interest in relation with this study.

\section{AUTHORS' CONTRIBUTIONS}

C. Richard and E.D. Lewis performed the literature review and the extraction of data. C.J. Field provided significant expertise to this expert review. C. Richard wrote the review with the help of E.D. Lewis, which was reviewed critically by all authors.

\section{ACKNOWLEDGEMENTS}

C.R. is recipient of postdoctoral fellow scholarships from Canadian Institutes of Health Research, Fonds de Recherche en Santé du Québec and Izaak Walton Killam Memorial Postdoctoral Fellowships. EDL is recipient of a Natural Sciences and Engineering Research Council (NSERC) Doctoral Postgraduate Scholarship and Izaak Walton Killam Memorial Scholarship. Research supported by an NSERC Discovery Grant to C. Field. 


\section{REFERENCES}

Adkins, B., Bu, Y., and Guevara, P. 2001. The generation of Th memory in neonates versus adults: prolonged primary Th2 effector function and impaired development of Th1 memory effector function in murine neonates. J Immunol 166(2): 918-25.

Albers, R., Antoine, J.M., Bourdet-Sicard, R., Calder, P.C., Gleeson, M., Lesourd, B., Samartin, S., Sanderson, I.R., Van Loo, J., Vas Dias, F.W., and Watzl, B. 2005. Markers to measure immunomodulation in human nutrition intervention studies. Br J Nutr 94(3): 452-81.

Atwell, K., Collins, C.T., Sullivan, T.R., Ryan, P., Gibson, R.A., Makrides, M., and McPhee, A.J. 2013. Respiratory hospitalisation of infants supplemented with docosahexaenoic acid as preterm neonates. J Paediatr Child Health 49(1): E17-22.

Bassaganya-Riera, J., Guri, A.J., Noble, A.M., Reynolds, K.A., King, J., Wood, C.M., Ashby, M., Rai, D., and Hontecillas, R. 2007. Arachidonic acid-and docosahexaenoic acid-enriched formulas modulate antigen-specific T cell responses to influenza virus in neonatal piglets. Am J Clin Nutr 85(3): 824-36.

Birch, E.E., Khoury, J.C., Berseth, C.L., Castaneda, Y.S., Couch, J.M., Bean, J., Tamer, R., Harris, C.L., Mitmesser, S.H., and Scalabrin, D.M. 2010. The impact of early nutrition on incidence of allergic manifestations and common respiratory illnesses in children. J Pediatr 156(6): 902-6, 906 e1.

Blumer, N., Pfefferle, P.I., and Renz, H. 2007. Development of mucosal immune function in the intrauterine and early postnatal environment. Curr Opin Gastroenterol 23(6): 655-60.

Blumer, N. and Renz, H. 2007. Consumption of omega3-fatty acids during perinatal life: role in immuno-modulation and allergy prevention. J Perinat Med 35 Suppl 1: S12-8.

Brenna, J.T., Varamini, B., Jensen, R.G., Diersen-Schade, D.A., Boettcher, J.A., and Arterburn, L.M. 2007. Docosahexaenoic and arachidonic acid concentrations in human breast milk worldwide. Am J Clin Nutr 85(6): 1457-64. 
Businco, L., Ioppi, M., Morse, N.L., Nisini, R., and Wright, S. 1993. Breast milk from mothers of children with newly developed atopic eczema has low levels of long chain polyunsaturated fatty acids. J Allergy Clin Immunol 91(6): 1134-9.

Calder, P.C., Krauss-Etschmann, S., de Jong, E.C., Dupont, C., Frick, J.S., Frokiaer, H., Heinrich, J., Garn, H., Koletzko, S., Lack, G., Mattelio, G., Renz, H., Sangild, P.T., Schrezenmeir, J., Stulnig, T.M., Thymann, T., Wold, A.E., and Koletzko, B. 2006. Early nutrition and immunity - progress and perspectives. Br J Nutr 96(4): 774-90.

Calder, P.C. 2008. The relationship between the fatty acid composition of immune cells and their function. Prostaglandins Leukot Essent Fatty Acids 79(3-5): 101-8.

Calder, P.C., Kremmyda, L.S., Vlachava, M., Noakes, P.S., and Miles, E.A. 2010. Is there a role for fatty acids in early life programming of the immune system? Proc Nutr Soc 69(3): 373-80.

Carnielli, V.P., Simonato, M., Verlato, G., Luijendijk, I., De Curtis, M., Sauer, P.J., and Cogo, P.E. 2007. Synthesis of long-chain polyunsaturated fatty acids in preterm newborns fed formula with longchain polyunsaturated fatty acids. Am J Clin Nutr 86(5): 1323-30.

Crawford, M.A., Wang, Y., Forsyth, S., and Brenna, J.T. 2015. The European Food Safety Authority recommendation for polyunsaturated fatty acid composition of infant formula overrules breast milk, puts infants at risk, and should be revised. Prostaglandins Leukot Essent Fatty Acids.

D'Vaz, N., Meldrum, S.J., Dunstan, J.A., Lee-Pullen, T.F., Metcalfe, J., Holt, B.J., Serralha, M., Tulic, M.K., Mori, T.A., and Prescott, S.L. 2012a. Fish oil supplementation in early infancy modulates developing infant immune responses. Clin Exp Allergy 42(8): 1206-16.

D'Vaz, N., Meldrum, S.J., Dunstan, J.A., Martino, D., McCarthy, S., Metcalfe, J., Tulic, M.K., Mori, T.A., and Prescott, S.L. 2012b. Postnatal fish oil supplementation in high-risk infants to prevent allergy: randomized controlled trial. Pediatrics 130(4): 674-82. 
Damsgaard, C.T., Lauritzen, L., Kjaer, T.M., Holm, P.M., Fruekilde, M.B., Michaelsen, K.F., and Frokiaer, H. 2007. Fish oil supplementation modulates immune function in healthy infants. J Nutr 137(4): 1031-6.

Delplanque, B., Gibson, R., Koletzko, B., Lapillonne, A., and Strandvik, B. 2015. Lipid Quality in Infant Nutrition: Current Knowledge and Future Opportunities. J Pediatr Gastroenterol Nutr 61(1): 817.

Duchen, K., Casas, R., Fageras-Bottcher, M., Yu, G., and Bjorksten, B. 2000. Human milk polyunsaturated long-chain fatty acids and secretory immunoglobulin A antibodies and early childhood allergy. Pediatr Allergy Immunol 11(1): 29-39.

Dunstan, J.A., Mori, T.A., Barden, A., Beilin, L.J., Taylor, A.L., Holt, P.G., and Prescott, S.L. 2003. Fish oil supplementation in pregnancy modifies neonatal allergen-specific immune responses and clinical outcomes in infants at high risk of atopy: a randomized, controlled trial. J Allergy Clin Immunol 112(6): 1178-84.

Dunstan, J.A. and Prescott, S.L. 2005. Does fish oil supplementation in pregnancy reduce the risk of allergic disease in infants? Curr Opin Allergy Clin Immunol 5(3): 215-21.

Fan, Y.Y., Ly, L.H., Barhoumi, R., McMurray, D.N., and Chapkin, R.S. 2004. Dietary docosahexaenoic acid suppresses $\mathrm{T}$ cell protein kinase $\mathrm{C}$ theta lipid raft recruitment and IL-2 production. J Immunol 173(10): 6151-60.

FAO/WHO 1994. Fats and oils in human nutrition. Report of a joint expert consultation. Food and Agriculture Organization of the United Nations and the World Health Organization. FAO Food Nutr Pap 57: i-xix, 1-147.

Field, C.J., Thomson, C.A., Van Aerde, J.E., Parrott, A., Euler, A., Lien, E., and Clandinin, M.T. 2000. Lower proportion of CD45R0+ cells and deficient interleukin-10 production by formula-fed infants, 
compared with human-fed, is corrected with supplementation of long-chain polyunsaturated fatty acids. J Pediatr Gastroenterol Nutr 31(3): 291-9.

Field, C.J., Clandinin, M.T., and Van Aerde, J.E. 2001. Polyunsaturated fatty acids and T-cell function: implications for the neonate. Lipids 36(9): 1025-32.

Field, C.J., Van Aerde, J.E., Robinson, L.E., and Clandinin, M.T. 2008a. Effect of providing a formula supplemented with long-chain polyunsaturated fatty acids on immunity in full-term neonates. Br J Nutr 99(1): 91-9.

Field, C.J., Van Aerde, J.E., Robinson, L.E., and Clandinin, M.T. 2008b. Feeding a formula supplemented with long chain polyunsaturated fatty acids modifies the "ex vivo" cytokine responses to food proteins in infants at low risk for allergy. Pediatr Res 64(4): 411-7.

Field, C.J., Van Aerde, J.E., Goruk, S., and Clandinin, M.T. 2010. Effect of feeding a formula supplemented with long-chain polyunsaturated fatty acids for 14 weeks improves the ex vivo response to a mitogen and reduces the response to a soy protein in infants at low risk for allergy. J Pediatr Gastroenterol Nutr 50(6): 661-9.

Fritsche, K. 2007. Important differences exist in the dose-response relationship between diet and immune cell fatty acids in humans and rodents. Lipids 42(11): 961-79.

Furuhjelm, C., Warstedt, K., Larsson, J., Fredriksson, M., Bottcher, M.F., Falth-Magnusson, K., and Duchen, K. 2009. Fish oil supplementation in pregnancy and lactation may decrease the risk of infant allergy. Acta Paediatr 98(9): 1461-7.

Furuhjelm, C., Jenmalm, M.C., Falth-Magnusson, K., and Duchen, K. 2011a. Th1 and Th2 chemokines, vaccine-induced immunity, and allergic disease in infants after maternal omega-3 fatty acid supplementation during pregnancy and lactation. Pediatr Res 69(3): 259-64. 
Furuhjelm, C., Warstedt, K., Fageras, M., Falth-Magnusson, K., Larsson, J., Fredriksson, M., and Duchen, K. 2011b. Allergic disease in infants up to 2 years of age in relation to plasma omega-3 fatty acids and maternal fish oil supplementation in pregnancy and lactation. Pediatr Allergy Immunol 22(5): 505-14.

Garside, P. and Mowat, A.M. 2001. Oral tolerance. Semin Immunol 13(3): 177-85.

Gould, J.F., Smithers, L.G., and Makrides, M. 2013. The effect of maternal omega-3 (n-3) LCPUFA supplementation during pregnancy on early childhood cognitive and visual development: a systematic review and meta-analysis of randomized controlled trials. Am J Clin Nutr 97(3): 531-44.

Granot, E., Jakobovich, E., Rabinowitz, R., Levy, P., and Schlesinger, M. 2011. DHA supplementation during pregnancy and lactation affects infants' cellular but not humoral immune response. Mediators Inflamm 2011: 493925.

Gunaratne, A.W., Makrides, M., and Collins, C.T. 2015. Maternal prenatal and/or postnatal n-3 long chain polyunsaturated fatty acids (LCPUFA) supplementation for preventing allergies in early childhood. Cochrane Database Syst Rev 7: CD010085.

Harbige, L.S. 2003. Fatty acids, the immune response, and autoimmunity: a question of n-6 essentiality and the balance between n-6 and n-3. Lipids 38(4): 323-41.

Hartel, C., Adam, N., Strunk, T., Temming, P., Muller-Steinhardt, M., and Schultz, C. 2005. Cytokine responses correlate differentially with age in infancy and early childhood. Clin Exp Immunol 142(3): 446-53.

Health Council of the Netherlands (2001): Dietary Reference Intakes: Energy, Proteins, Fats and Digestible Carbohydrates. Publication no. 2001/19E. The Hague: Health Council of the Netherlands.

Holt, P.G. and Jones, C.A. 2000. The development of the immune system during pregnancy and early life. Allergy 55(8): 688-697. 
Hosea Blewett, H.J., Cicalo, M.C., Holland, C.D., and Field, C.J. 2008. The immunological components of human milk. Adv Food Nutr Res 54: 45-80.

Hwang, I., Cha, A., Lee, H., Yoon, H., Yoon, T., Cho, B., Lee, S., and Park, Y. 2007. N-3

polyunsaturated fatty acids and atopy in Korean preschoolers. Lipids 42(4): 345-9.

Janssen, C.I. and Kiliaan, A.J. 2014. Long-chain polyunsaturated fatty acids (LCPUFA) from genesis to senescence: the influence of LCPUFA on neural development, aging, and neurodegeneration. Prog Lipid Res 53: 1-17.

Kim, W., Khan, N.A., McMurray, D.N., Prior, I.A., Wang, N., and Chapkin, R.S. 2010. Regulatory activity of polyunsaturated fatty acids in T-cell signaling. Prog Lipid Res 49(3): 250-61.

Koletzko, B., Agostoni, C., Carlson, S.E., Clandinin, T., Hornstra, G., Neuringer, M., Uauy, R., Yamashiro, Y., and Willatts, P. 2001. Long chain polyunsaturated fatty acids (LC-PUFA) and perinatal development. Acta Paediatr 90(4): 460-4.

Koletzko, B., Carlson, S.E., and van Goudoever, J.B. 2015. Should Infant Formula Provide Both Omega-3 DHA and Omega-6 Arachidonic Acid? Ann Nutr Metab 66(2-3): 137-8.

Kremmyda, L.S., Vlachava, M., Noakes, P.S., Diaper, N.D., Miles, E.A., and Calder, P.C. 2011. Atopy risk in infants and children in relation to early exposure to fish, oily fish, or long-chain omega-3 fatty acids: a systematic review. Clin Rev Allergy Immunol 41(1): 36-66.

Lapillonne, A., Pastor, N., Zhuang, W., and Scalabrin, D.M. 2014. Infants fed formula with added long chain polyunsaturated fatty acids have reduced incidence of respiratory illnesses and diarrhea during the first year of life. BMC Pediatr 14: 168.

Lauritzen, L., Jorgensen, M.H., Mikkelsen, T.B., Skovgaard 1, M., Straarup, E.M., Olsen, S.F., Hoy, C.E., and Michaelsen, K.F. 2004. Maternal fish oil supplementation in lactation: effect on visual acuity and n-3 fatty acid content of infant erythrocytes. Lipids 39(3): 195-206. 
Lauritzen, L., Kjaer, T.M., Fruekilde, M.B., Michaelsen, K.F., and Frokiaer, H. 2005. Fish oil supplementation of lactating mothers affects cytokine production in 2 1/2-year-old children. Lipids 40(7): 669-76.

Lauritzen, L., Fewtrell, M., and Agostoni, C. 2015. Dietary arachidonic acid in perinatal nutrition: a commentary. Pediatr Res 77(1-2): 263-9.

Linnamaa, P., Savolainen, J., Koulu, L., Tuomasjukka, S., Kallio, H., Yang, B., Vahlberg, T., and Tahvonen, R. 2010. Blackcurrant seed oil for prevention of atopic dermatitis in newborns: a randomized, double-blind, placebo-controlled trial. Clin Exp Allergy 40(8): 1247-55.

Lowe, A.J., Thien, F.C., Stoney, R.M., Bennett, C.M., Hosking, C.S., Hill, D.J., Carlin, J.B., Abramson, M.J., and Dharmage, S.C. 2008. Associations between fatty acids in colostrum and breast milk and risk of allergic disease. Clin Exp Allergy 38(11): 1745-51.

M'Rabet, L., Vos, A.P., Boehm, G., and Garssen, J. 2008. Breast-feeding and its role in early development of the immune system in infants: consequences for health later in life. J Nutr 138(9): 1782S-1790S.

Manley, B.J., Makrides, M., Collins, C.T., McPhee, A.J., Gibson, R.A., Ryan, P., Sullivan, T.R., Davis, P.G., and DINO Steering Committee. 2011. High-dose docosahexaenoic acid supplementation of preterm infants: respiratory and allergy outcomes. Pediatrics 128(1): e71-7.

Mihrshahi, S., Peat, J.K., Marks, G.B., Mellis, C.M., Tovey, E.R., Webb, K., Britton, W.J., Leeder, S.R., and Childhood Asthma Prevention, S. 2003. Eighteen-month outcomes of house dust mite avoidance and dietary fatty acid modification in the Childhood Asthma Prevention Study (CAPS). J Allergy Clin Immunol 111(1): 162-8. 
Oddy, W.H., Pal, S., Kusel, M.M., Vine, D., de Klerk, N.H., Hartmann, P., Holt, P.G., Sly, P.D., Burton, P.R., Stanley, F.J., and Landau, L.I. 2006. Atopy, eczema and breast milk fatty acids in a highrisk cohort of children followed from birth to 5 yr. Pediatr Allergy Immunol 17(1): 4-10.

Osterlund, P. and Suomalainen, H. 2002. Low frequency of CD4+, but not CD8+, T cells expressing interferon-gamma is related to cow's milk allergy in infancy. Pediatr Allergy Immunol 13(4): 262-8.

Pastor, N., Soler, B., Mitmesser, S.H., Ferguson, P., and Lifschitz, C. 2006. Infants fed docosahexaenoic acid- and arachidonic acid-supplemented formula have decreased incidence of bronchiolitis/bronchitis the first year of life. Clin Pediatr (Phila) 45(9): 850-5.

Pawlosky, R.J., Lin, Y.H., Llanos, A., Mena, P., Uauy, R., and Salem, N., Jr. 2006. Compartmental analyses of plasma $13 \mathrm{C}$ - and $2 \mathrm{H}$-labeled n-6 fatty acids arising from oral administrations of 13C-U18:2n-6 and 2H5-20:3n-6 in newborn infants. Pediatr Res 60(3): 327-33.

Peat, J.K., Mihrshahi, S., Kemp, A.S., Marks, G.B., Tovey, E.R., Webb, K., Mellis, C.M., and Leeder, S.R. 2004. Three-year outcomes of dietary fatty acid modification and house dust mite reduction in the Childhood Asthma Prevention Study. J Allergy Clin Immunol 114(4): 807-13.

Perez-Cano, F.J., Franch, A., Castellote, C., and Castell, M. 2012. The suckling rat as a model for immunonutrition studies in early life. Clin Dev Immunol 2012: 537310.

Prescott, S.L. 2003. Early origins of allergic disease: a review of processes and influences during early immune development. Curr Opin Allergy Clin Immunol 3(2): 125-32.

Prescott, S.L. and Dunstan, J.A. 2007. Prenatal fatty acid status and immune development: the pathways and the evidence. Lipids 42(9): 801-10.

Richard, C., Lewis, E.D., Goruk, S., and Field, C.J. 2015. The content of docosahexaenoic acid in the maternal diet differentially affects the immune response in lactating dams and suckled offspring. Eur J Nutr. 
Romieu, I., Torrent, M., Garcia-Esteban, R., Ferrer, C., Ribas-Fito, N., Anto, J.M., and Sunyer, J. 2007. Maternal fish intake during pregnancy and atopy and asthma in infancy. Clin Exp Allergy 37(4): 51825.

Salam, M.T., Li, Y.F., Langholz, B., and Gilliland, F.D. 2005. Maternal fish consumption during pregnancy and risk of early childhood asthma. J Asthma 42(6): 513-8.

Sasaki, T., Kanke, Y., Kudoh, K., Misawa, Y., Shimizu, J., and Takita, T. 1999. Effects of dietary docosahexaenoic acid on surface molecules involved in T cell proliferation. Biochim Biophys Acta 1436(3): 519-30.

Simmer, K. 2000a. Long-chain polyunsaturated fatty acid supplementation in infants born at term. Cochrane Database Syst Rev(2): CD000376.

Simmer, K. 2000b. Long-chain polyunsaturated fatty acid supplementation in preterm infants. Cochrane Database Syst Rev(2): CD000375.

Simopoulos, A.P., Leaf, A., and Salem, N., Jr. 2000. Workshop statement on the essentiality of and recommended dietary intakes for Omega-6 and Omega-3 fatty acids. Prostaglandins Leukot Essent Fatty Acids 63(3): 119-21.

Sutas, Y., Hurme, M., and Isolauri, E. 1997. Oral cow milk challenge abolishes antigen-specific interferon-gamma production in the peripheral blood of children with atopic dermatitis and cow milk allergy. Clin Exp Allergy 27(3): 277-83.

Tang, M., Kemp, A., and Varigos, G. 1993. IL-4 and interferon-gamma production in children with atopic disease. Clin Exp Immunol 92(1): 120-4.

Uauy, R., Hoffman, D.R., Peirano, P., Birch, D.G., and Birch, E.E. 2001. Essential fatty acids in visual and brain development. Lipids 36(9): 885-95. 
van Odijk, J., Kull, I., Borres, M.P., Brandtzaeg, P., Edberg, U., Hanson, L.A., Host, A., Kuitunen, M., Olsen, S.F., Skerfving, S., Sundell, J., and Wille, S. 2003. Breastfeeding and allergic disease: a multidisciplinary review of the literature (1966-2001) on the mode of early feeding in infancy and its impact on later atopic manifestations. Allergy 58(9): 833-43.

Wijga, A.H., van Houwelingen, A.C., Kerkhof, M., Tabak, C., de Jongste, J.C., Gerritsen, J., Boshuizen, H., Brunekreef, B., and Smit, H.A. 2006. Breast milk fatty acids and allergic disease in preschool children: the Prevention and Incidence of Asthma and Mite Allergy birth cohort study. J Allergy Clin Immunol 117(2): 440-7.

Wright, S. and Bolton, C. 1989. Breast milk fatty acids in mothers of children with atopic eczema. Br J Nutr 62(3): 693-7.

Yuhas, R., Pramuk, K., and Lien, E.L. 2006. Human milk fatty acid composition from nine countries varies most in DHA. Lipids 41(9): 851-8.

Zeyda, M., Staffler, G., Horejsi, V., Waldhausl, W., and Stulnig, T.M. 2002. LAT displacement from lipid rafts as a molecular mechanism for the inhibition of $\mathrm{T}$ cell signaling by polyunsaturated fatty acids. J Biol Chem 277(32): 28418-23. 
Table 1: Evidence from epidemiological studies examining the association between LCPUFA breast milk composition and the development of immune system in infants or children

\begin{tabular}{|c|c|c|c|c|c|c|c|c|}
\hline$\frac{\vec{E}}{\tilde{E}}$ & 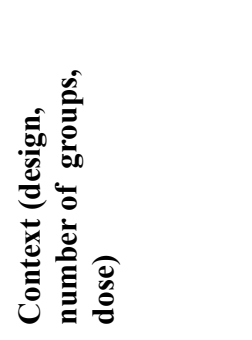 & : & 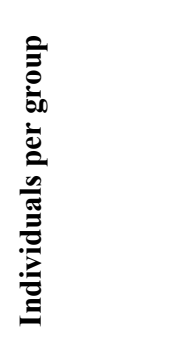 & 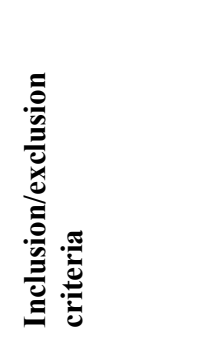 & 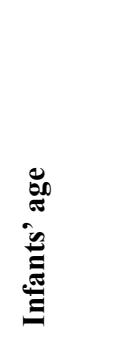 & 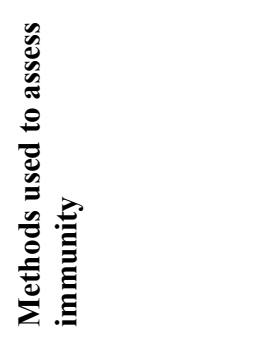 & 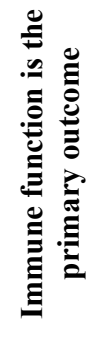 & Results \\
\hline $\begin{array}{l}\text { (Lowe et al. } \\
2008 \text { ) }\end{array}$ & Prospective cohort & Aus & $\begin{array}{l}\mathrm{N}=224 \\
(\mathrm{~N}=194 \\
\text { mothers } \\
\text { provided } \\
\text { colostrum; } \\
\mathrm{N}=118 \\
\text { provided } \\
\mathrm{BM})\end{array}$ & $\begin{array}{l}\text { High risk } \\
\text { cohort, family } \\
\text { member with } \\
\text { history of } \\
\text { atopic disease }\end{array}$ & $\begin{array}{l}\text { Every } \\
\text { year for } \\
7 \text { years }\end{array}$ & $\begin{array}{l}\text { Breast milk } \\
\text { collected and FA } \\
\text { assessed by GC; } \\
\text { SPT for allergens at } \\
6,12 \text { and } 24 \text { months; } \\
\text { Telephone surveys } \\
\text { with nurse to assess } \\
\text { allergy symptoms }\end{array}$ & Yes & $\begin{array}{l}\text { 1) High levels of DHA in colostrum associated } \\
\text { with increased risk of infant with atopic eczema } \\
(\mathrm{OR}=1.6,95 \% \text { CI } 1.11-2.48) ; 2 \text { ) Total n-3 } \\
\text { concentrations associated with increased risk of } \\
\text { non-atopic eczema (OR-1.60, } 95 \% \text { CI } 1.03-2.50) \text {, } \\
\text { effect due to ALA; } 3 \text { ) Higher levels of n- } 6 \text { in } \\
\text { colostrum associated with increased risk of infant } \\
\text { rhinitis, effect due to LA; 4) Reduced risk of } \\
\text { asthma with high DHA and low n- } 6 / n-3 \text { ratio but } \\
\text { did not reach significance }\end{array}$ \\
\hline $\begin{array}{l}\text { (Oddy et al. } \\
2006)\end{array}$ & $\begin{array}{l}\text { Prospective birth } \\
\text { cohort (Childhood } \\
\text { Asthma Study) }\end{array}$ & Aus & $\begin{array}{l}\mathrm{N}=91 \text { atopic } \\
\text { (history of } \\
\text { asthma, } \\
\text { hayfever or } \\
\text { eczema) } \\
\text { mothers and } \\
\text { their infants }\end{array}$ & $\begin{array}{l}\text { Infants at high } \\
\text { risk of atopy, } \\
\text { family history } \\
\text { of atopy }\end{array}$ & $\begin{array}{l}6 \text { weeks, } \\
6 \\
\text { months }\end{array}$ & $\begin{array}{l}\text { Breast milk } \\
\text { collected at } 6 \text { wks } \\
\text { and } 6 \text { months, FA } \\
\text { assessed by GC; } \\
\text { SPT at } 6 \text { months } \\
\text { assessed atopy, } \\
\text { physical assessment } \\
\text { for eczema }\end{array}$ & Yes & $\begin{array}{l}\text { 1) Increased n-6/n-3 ratio in milk of mothers of } \\
\text { infants with non-atopic eczema at } 6 \text { months; } 2 \text { ) } \\
\text { Due to reduced DHA and EPA levels and } \\
\text { increased LA in milk; 3) No difference in FA } \\
\text { composition for atopy alone or atopic eczema }\end{array}$ \\
\hline $\begin{array}{l}\text { (Wijga et } \\
\text { al. 2006) }\end{array}$ & $\begin{array}{l}\text { PIAMA } \\
\text { prospective birth } \\
\text { cohort (Prevention } \\
\text { and Incidence of } \\
\text { Asthma and Mite } \\
\text { Allergy) }\end{array}$ & $\begin{array}{l}\text { Nether } \\
\text { lands }\end{array}$ & $\begin{array}{l}\mathrm{N}=265 \\
\text { mothers and } \\
\text { infants }(158 \\
\text { allergic and } \\
107 \text { non- } \\
\text { allergic) }\end{array}$ & $\begin{array}{l}\text { Allergic } \\
\text { mothers had } \\
\text { to family } \\
\text { member with } \\
\text { history of } \\
\text { atopic disease }\end{array}$ & $\begin{array}{l}1 \text { and } 4 \\
\text { years }\end{array}$ & $\begin{array}{l}\text { Breast milk } \\
\text { collected and FA } \\
\text { assessed by GC; } \\
\text { Parental } \\
\text { questionnaire based } \\
\text { on previous study } \\
\text { assessed eczema } \\
\text { and asthma; Blood } \\
\text { samples at } 4 \text { years } \\
\text { to assess IgE levels } \\
\text { to allergens }\end{array}$ & Yes & $\begin{array}{l}\text { 1) In children of mothers with allergy, breast milk } \\
\text { n-3 LCPUFA and n-3/n- } 6 \text { ratio inversely } \\
\text { associated with asthma at } 4 \text { years old (highest } \\
\text { association with total n-3); 2) No association } \\
\text { between breast milk FA composition and } \\
\text { sensitization; 3) In children of mothers with allergy } \\
\text { inverse association of AA and allergic symptoms; } \\
\text { 4) No associations with FA composition and } \\
\text { allergies in children of mothers without allergy }\end{array}$ \\
\hline $\begin{array}{l}\text { (Duchén et } \\
\text { al. 2000) }\end{array}$ & Prospective cohort & $\begin{array}{l}\text { Swede } \\
\mathrm{n}\end{array}$ & $\begin{array}{l}\mathrm{N}=57 \text { non- } \\
\text { atopic } \\
\text { mothers and } \\
\text { infants } \\
\text { (non- } \\
\text { allergic); }\end{array}$ & $\begin{array}{l}\text { Healthy } \\
\text { infants at } \\
\text { birth; } \\
\text { Exclusive } \\
\text { breast-feeding } \\
\text { for }>3 \text { months }\end{array}$ & $\begin{array}{l}3-18 \\
\text { months }\end{array}$ & $\begin{array}{l}\text { Breast milk } \\
\text { collected mid- } \\
\text { morning at } 2-4 \text { days } \\
\text { postpartum and } \\
\text { monthly, FA } \\
\text { assessed by GC; }\end{array}$ & Yes & $\begin{array}{l}\text { 1) Lower levels of DHA (and EPA, DPA) in milk } \\
\text { from mothers with allergic children compared to } \\
\text { mothers with non-allergic children; 2) AA and } \\
\text { EPA ratio higher in milk from mothers with } \\
\text { allergic children; 3) Total sIgA in milk at } 3 \text { months } \\
\text { was not different between groups; 4) Low DHA }\end{array}$ \\
\hline
\end{tabular}




\begin{tabular}{|c|c|c|c|c|c|c|c|c|}
\hline & & & $\begin{array}{l}\mathrm{N}=63 \text { atopic } \\
\text { mothers and } \\
\text { infants } \\
\text { (allergic) }\end{array}$ & & & $\begin{array}{l}\text { sIgA assessed using } \\
\text { ELISA; SPT at } \\
6,12,18 \text { months } \\
\text { assess development } \\
\text { of atopic disease in } \\
\text { children }\end{array}$ & & $\begin{array}{l}\text { and high AA:DHA ratio in milk associated with } \\
\text { development of symptoms of allergic disease at } 18 \\
\text { months }\end{array}$ \\
\hline $\begin{array}{l}\text { (Businco et } \\
\text { al. 1993) }\end{array}$ & $\begin{array}{l}\text { Case control } \\
\text { cohort }\end{array}$ & Italy & $\begin{array}{l}\mathrm{N}=23 \\
\text { children } \\
\text { with atopic } \\
\text { dermatitis; } \mathrm{N} \\
=18 \text { control } \\
\text { children }\end{array}$ & $\begin{array}{l}\text { Infants newly } \\
\text { diagnosed } \\
\text { with atopic } \\
\text { dermatitis; } \\
\text { Control group } \\
\text { had no history } \\
\text { of atopic } \\
\text { disease }\end{array}$ & $\begin{array}{l}3-6 \\
\text { months }\end{array}$ & $\begin{array}{l}\text { Atopic disease } \\
\text { confirmed by SPT } \\
\text { and total IgE; Breast } \\
\text { milk collected and } \\
\text { FA assessed by GC }\end{array}$ & Yes & $\begin{array}{l}\text { 1) Breast milk oleic acid (18:1n-9) content was } \\
\text { higher in atopic group; 2) No significant difference } \\
\text { in AA or DHA breast milk content between groups }\end{array}$ \\
\hline $\begin{array}{l}\text { (Wright and } \\
\text { Bolton } \\
1989)\end{array}$ & $\begin{array}{l}\text { Case control } \\
\text { cohort }\end{array}$ & $\begin{array}{l}\text { Zimba } \\
\text { bwe }\end{array}$ & $\begin{array}{l}\mathrm{N}=25 \text { atopic } \\
\text { children and } \\
\text { their } \\
\text { mothers; } \\
\mathrm{N}=22 \\
\text { control } \\
\text { children }\end{array}$ & $\begin{array}{l}\text { Child with } \\
\text { atopic } \\
\text { eczema; } \\
\text { Control } \\
\text { infants with } \\
\text { non- } \\
\text { eczematous } \\
\text { conditions }\end{array}$ & $\begin{array}{l}2-6 \\
\text { months }\end{array}$ & $\begin{array}{l}\text { Clinical symptoms } \\
\text { of eczema } \\
\text { confirmed by } \\
\text { physician; Breast } \\
\text { milk collected and } \\
\text { FA assessed by GC }\end{array}$ & Yes & $\begin{array}{l}\text { 1) In the atopic eczema group, breast milk } \\
\text { contained a higher proportion of LA and ALA; 2) } \\
\text { There was no difference in the proportion of DHA } \\
\text { or EPA in breast milk between groups }\end{array}$ \\
\hline
\end{tabular}

AA, arachidonic acid; ALA, $\alpha$-linolenic acid; Aus, Australia; CCL, CC-chemokine ligand; CXCL, chemokine (C-X-C motif) ligand; DHA, docosahexaenoic acid; EPA, eicosapentaenoic; FA, fatty acid; GC, gas chromatography; IFN- $\gamma$, interferon-gamma; Ig, immunoglobulin; IL, interleukin; LA, linoleic acid; LPS, lipopolysaccharide; n, omega; SPT, skin prick test. 
Table 2: Evidence from intervention studies on the impact of AA and DHA supplementation in the postnatal infant diet on immune system and oral tolerance development

\begin{tabular}{|c|c|c|c|c|c|c|c|c|c|}
\hline$\stackrel{\frac{D}{E}}{D}$ & 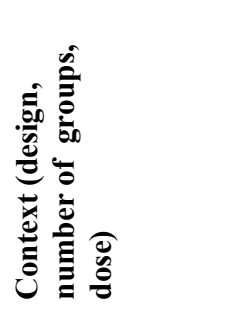 & : & 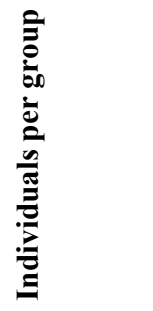 & 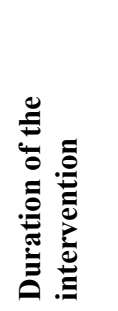 & 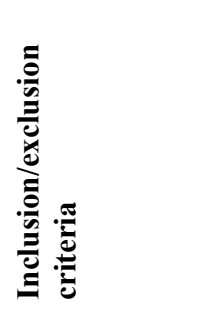 & 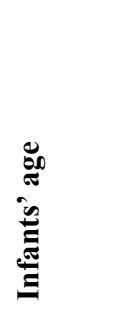 & 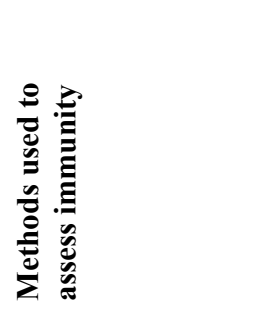 & 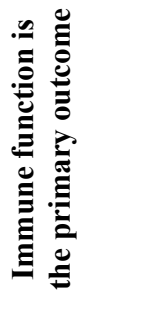 & Results \\
\hline $\begin{array}{l}\text { (Lapillonn } \\
\text { e et al. } \\
\text { 2014) }\end{array}$ & $\begin{array}{l}\text { Prospective, } \\
\text { observational, } \\
\text { open label; } 2 \\
\text { groups: formula } \\
\text { with } 34 \mathrm{mg} \text { AA } \\
\text { and } 17 \mathrm{mg} \text { DHA } \\
\text { vs. control (no } \\
\text { added AA and } \\
\text { DHA) }\end{array}$ & France & $\begin{array}{l}\mathrm{N}=233 \\
\mathrm{AA} \text { and } \\
\mathrm{DHA} ; \\
\mathrm{N}=92 \\
\text { Control }\end{array}$ & $\begin{array}{l}12 \\
\text { months }\end{array}$ & $\begin{array}{l}\text { Healthy } \\
\text { infants, born } \\
\text { after } 37 \text { wks; } \\
\text { Appropriate } \\
\text { for } \\
\text { gestational } \\
\text { age }<\text { than } 60 \\
\text { days at } \\
\text { enrolment }\end{array}$ & $\begin{array}{l}12 \\
\text { month } \\
\mathrm{s}\end{array}$ & $\begin{array}{l}5 \text { pediatrician } \\
\text { visits assessed } \\
\text { respiratory } \\
\text { symptoms and } \\
\text { illnesses }\end{array}$ & Yes & $\begin{array}{l}\text { 1) Infants consuming formula with AA and DHA } \\
\text { had lower incidence of bronchitis, croup, nasal } \\
\text { congestion, cough; 2) Diarrhea that required } \\
\text { medical attention was lower in DHA and AA } \\
\text { group; 3) OR of increased number of incidences } \\
\text { and hazard ratio for shorter time to first incidence } \\
\text { of mentioned illnesses was lower in DHA and AA } \\
\text { group }\end{array}$ \\
\hline $\begin{array}{l}\text { (D'Vaz et } \\
\text { al. 2012) }\end{array}$ & $\begin{array}{l}\text { Double blinded, } \\
\text { randomized } \\
\text { placebo- } \\
\text { controlled trial; } 2 \\
\text { groups: fish oil } \\
\text { (650mg of fish oil } \\
\text { containing } 110 \mathrm{mg} \\
\text { EPA and } 280 \mathrm{mg} \\
\text { DHA) or control } \\
\text { (650 mg olive oil) }\end{array}$ & Aus & $\begin{array}{l}\mathrm{N}=218 \\
\text { fish oil; } \\
\mathrm{N}=202 \\
\text { control }\end{array}$ & $\begin{array}{l}\text { Birth-6 } \\
\text { months }\end{array}$ & $\begin{array}{l}\text { Healthy term } \\
\text { infants born } \\
\text { from allergic } \\
\text { women (high } \\
\text { risk of atopic } \\
\text { diseases) }\end{array}$ & $\begin{array}{l}6 \& 12 \\
\text { months }\end{array}$ & $\begin{array}{l}\text { Eczema, food } \\
\text { allergy, asthma } \\
\text { and sensitization } \\
\text { (SPT) assessed at } \\
12 \text { months; } \\
\text { Allergic diseases } \\
\text { defined as IgE- } \\
\text { mediated food } \\
\text { allergy, eczema or } \\
\text { asthma }\end{array}$ & Yes & $\begin{array}{l}\text { 1) Higher content of EPA and DHA and lower } \\
\text { content of AA in erythrocytes in the fish oil vs. } \\
\text { control group; 2) No difference between groups in } \\
\text { the prevalence of allergic outcomes (any allergic } \\
\text { diseases, sensitization, eczema) at } 12 \text { months as } \\
\text { well as in recurrent wheeze or persistent coughing } \\
\text { at } 6 \text { and } 12 \text { months; 3) Plasma levels of DHA at } 6 \\
\text { months was negatively associated with recurrent } \\
\text { wheeze in the first } 12 \text { months of life }\end{array}$ \\
\hline $\begin{array}{l}\text { (D'Vaz et } \\
\text { al. 2012) } \\
\text { *Second } \\
\text { publication } \\
\text { from the } \\
\text { above study }\end{array}$ & $\begin{array}{l}\text { Double blinded, } \\
\text { randomized } \\
\text { placebo- } \\
\text { controlled trial; } \underline{2} \\
\text { groups: fish oil } \\
\text { (650mg of fish oil } \\
\text { containing } 110 \mathrm{mg} \\
\text { EPA and } 280 \mathrm{mg} \\
\text { DHA) or control } \\
\text { (650 mg olive oil) }\end{array}$ & Aus & $\begin{array}{l}\mathrm{N}=69 \text { fish } \\
\text { oil; } \mathrm{N}=81 \\
\text { control }\end{array}$ & $\begin{array}{l}\text { Birth-6 } \\
\text { months }\end{array}$ & $\begin{array}{l}\text { Healthy term } \\
\text { infants born } \\
\text { from allergic } \\
\text { women (high } \\
\text { risk of atopic } \\
\text { diseases) }\end{array}$ & $\begin{array}{l}6 \text { and } 12 \\
\text { months }\end{array}$ & $\begin{array}{l}\text { Phenotyping of } \\
\text { lymphocytes; } \\
\text { Measurement of } \\
\text { cytokine } \\
\text { production by } \\
\text { lymphocytes } \\
\text { stimulated with } \\
\text { food antigens } \\
\text { (OVA \& BLG) or } \\
\text { mitogens (PHA \& } \\
\text { LPS) }\end{array}$ & $\begin{array}{l}\text { No } \\
\text { (immune } \\
\text { developm } \\
\text { ent as a } \\
\text { secondary } \\
\text { outcome) }\end{array}$ & $\begin{array}{l}\text { 1) Lower IL-13 production in response to house } \\
\text { dust mite (HDM) and higher IFN- } \gamma \text { and TNF- } \alpha \\
\text { responses to PHA in the fish oil vs. control group; } \\
\text { 2) Higher plasma DHA levels was associated with } \\
\text { lower Th2 responses to allergens including lower } \\
\text { IL-13 and IL- } 5 \text { production after BLG stimulation. } \\
\text { Lower plasma DHA level was a predictor of } \\
\text { eczema by } 12 \text { months; } 3 \text { ) Egg sensitisation was } \\
\text { predicted by IL-13 and IL-5 responses to OVA at } \\
6 \text { months; } 4 \text { ) IL-5, IL-13 and IFN- } \gamma \text { production } \\
\text { after stimulation with HDM was higher in infant } \\
\text { with eczema at } 6 \& 12 \text { months }\end{array}$ \\
\hline
\end{tabular}




\begin{tabular}{|c|c|c|c|c|c|c|c|c|c|}
\hline $\begin{array}{l}\text { (Birch et al. } \\
2010)\end{array}$ & $\begin{array}{l}\text { Double blinded, } \\
\text { randomized } \\
\text { controlled trial; } 2 \text { } \\
\text { groups: standard } \\
\text { infant formula and } \\
\text { supplemented } \\
\text { infant formula } \\
(0.64-0.72 \% \text { AA } \\
\text { and } 0.32-0.36 \% \\
\text { DHA of total FA) }\end{array}$ & $\begin{array}{l}\text { USA } \\
\text { (Dallas) }\end{array}$ & $\begin{array}{l}\mathrm{N}=51 \\
\text { standard } \\
\text { formula; } \\
\mathrm{N}=38 \\
\text { formula } \\
+\mathrm{LCPUF} \\
\mathrm{A}\end{array}$ & $\begin{array}{l}12 \\
\text { months; } \\
\text { From } 5 \\
\text { days of } \\
\text { age to } \\
12 \\
\text { months }\end{array}$ & $\begin{array}{l}\text { Infants had to } \\
\text { be healthy } \\
\text { and born } \\
\text { between } 37- \\
40 \text { weeks of } \\
\text { gestational } \\
\text { age }\end{array}$ & 3 years & $\begin{array}{l}\text { Medical charts } \\
\text { were reviewed for } \\
\text { upper respiratory } \\
\text { infection (URI), } \\
\text { wheezing, asthma, } \\
\text { bronchitis, } \\
\text { pneumonia, } \\
\text { allergic rhinitis, } \\
\text { food allergy, } \\
\text { atopic dermatitis } \\
\text { (AD)... }\end{array}$ & No & $\begin{array}{l}\text { 1) The formula+LCPUFA group had significantly } \\
\text { lower odds for developing URI (OR: } 0.22 \text { ), } \\
\text { wheezing/asthma/AD (OR: } 0.25 \text { ) or any allergy } \\
\text { (OR: } 0.28) ; 2 \text { ) The control group had significantly } \\
\text { shorter time before first diagnosis of URI, } \\
\text { wheezing/asthma or any allergy; 3) Any allergy } \\
\text { refers to any one of the following manifestations: } \\
\text { wheezing, asthma, AD, allergic rhinitis, allergic } \\
\text { conjunctivitis, food allergy and urticarial }\end{array}$ \\
\hline $\begin{array}{l}\text { (Field et al. } \\
2010)\end{array}$ & $\begin{array}{l}\text { Randomized, } \\
\text { double blind, } \\
\text { controlled trial; } \underline{3} \\
\text { groups: standard } \\
\text { formula, formula } \\
\text { + LCPUFA } \\
(0.34 \% \mathrm{w} / \mathrm{w} \mathrm{AA} \\
\text { and } 0.2 \% \mathrm{w} / \mathrm{w} \\
\text { DHA of total FA) } \\
\text { and human milk } \\
\text { as a comparison } \\
\text { group }\end{array}$ & Canada & $\begin{array}{l}\mathrm{N}=14 \\
\text { standard } \\
\text { formula; } \\
\mathrm{N}=16 \\
\text { formula } \\
+\mathrm{LCPUF} \\
\mathrm{A} ; \mathrm{N}=16 \\
\text { human } \\
\text { milk }\end{array}$ & $\begin{array}{l}14 \\
\text { weeks; } \\
\text { From } 14 \\
\text { days of } \\
\text { life to } \\
16 \\
\text { weeks }\end{array}$ & $\begin{array}{l}\text { Infants had to } \\
\text { be heathy } \\
\text { with growth } \\
\text { parameters } \\
\text { between } 10- \\
90^{\text {th }} \\
\text { percentile; } \\
\text { Low risk of } \\
\text { allergy }\end{array}$ & $\begin{array}{l}16 \\
\text { weeks } \\
(3.5 \\
\text { months })\end{array}$ & $\begin{array}{l}\text { Phenotyping of } \\
\text { PBMC and } \\
\text { cytokine } \\
\text { production after } \\
\text { stimulation with } \\
\text { mitogen (PHA) or } \\
\text { food proteins } \\
\text { (BLG and SOY) } \\
\text { and estimation of } \\
\text { proliferation using } \\
\text { the }\left[{ }^{3} \mathrm{H}\right] \text { thymidine } \\
\text { uptake method }\end{array}$ & Yes & $\begin{array}{l}\text { 1) At } 16 \text { weeks, lower proportion of total cells } \\
\text { expressing CD } 45 \text { RO+ (pre-culture) in the formula } \\
\text { vs. HM \& formula+LCPUFA group; 2) Both } \\
\text { formula groups produced less IL-2 after PHA vs. } \\
\text { HM group. Formula+LCPUFA and HM had a } \\
\text { more similar proliferation rate to PHA vs. } \\
\text { formula group; 3) Lower IL- } 4 \text { (higher IFN- } \gamma / \text { IL-4 } \\
\text { ratio) production after PHA stimulation in the } \\
\text { formula+LCPUFA vs. formula group; 4) Lower } \\
\text { IL-2 and higher TNF- } \alpha \text { production after SOY } \\
\text { stimulation in the formula+LCPUFA vs. formula } \\
\text { group }\end{array}$ \\
\hline $\begin{array}{l}\text { (Field et al. } \\
\text { 2008) }\end{array}$ & $\begin{array}{l}\text { Randomized, } \\
\text { double blind, } \\
\text { controlled trial; } \underline{3} \\
\text { groups: standard } \\
\text { formula, formula } \\
+ \text { LCPUFA } \\
(0.34 \% \mathrm{w} / \mathrm{w} \mathrm{AA} \\
\text { and } 0.2 \% \mathrm{w} / \mathrm{w} \\
\text { DHA of total FA) } \\
\text { and human milk }\end{array}$ & Canada & $\begin{array}{l}\mathrm{N}=14 \\
\text { standard } \\
\text { formula; } \\
\mathrm{N}=16 \\
\text { formula } \\
+\mathrm{LCPUF} \\
\mathrm{A} ; \mathrm{N}=16 \\
\text { human } \\
\text { milk }\end{array}$ & $\begin{array}{l}4 \\
\text { weeks; } \\
\text { From } 14 \\
\text { days of } \\
\text { life to } 6 \\
\text { weeks }\end{array}$ & $\begin{array}{l}\text { Infants had to } \\
\text { be heathy } \\
\text { with growth } \\
\text { parameters } \\
\text { between } 10- \\
90^{\text {th }} \\
\text { percentile; } \\
\text { Low risk of } \\
\text { allergy }\end{array}$ & $\begin{array}{l}6 \text { weeks } \\
(1.5 \\
\text { month) }\end{array}$ & $\begin{array}{l}\text { Phenotyping of } \\
\text { lymphocytes and } \\
\text { cytokine } \\
\text { production after } \\
\text { PHA stimulation } \\
\text { and estimation of } \\
\text { lymphocytes } \\
\text { proliferation using } \\
\text { the }\left[{ }^{3} \mathrm{H}\right] \text { thymidine } \\
\text { uptake method }\end{array}$ & Yes & $\begin{array}{l}\text { 1) At } 6 \text { weeks, the formula+LCPUFA had a lower } \\
\text { proliferation rate to PHA (but not IL- } 2 \\
\text { production) vs. HM group; } 2 \text { ) The } \\
\text { formula+LCPUFA had higher \% of CD } 3+\text { CD } 44+ \\
\text { and CD } 4+\text { CD } 28+\text { cells (pre-culture) and lower } \\
\text { TNF- } \alpha \text { production after PHA stimulation (that did } \\
\text { not differ from HM group) vs. formula group; } 3 \text { ) } \\
\text { Both formula groups produced more IFN- } \gamma \text { after } \\
\text { PHA stimulation and had a higher } \% \text { of helper T } \\
\text { cells and lower \% of CD } 16+C D 11 \mathrm{c}+\text { cells (post- } \\
\text { culture) vs. HM }\end{array}$ \\
\hline $\begin{array}{l}\text { (Field et al. } \\
2008 \text { ) } \\
\text { *Second } \\
\text { publication } \\
\text { from the } \\
\text { above study }\end{array}$ & $\begin{array}{l}\text { Randomized, } \\
\text { double blind, } \\
\text { controlled trial; } \underline{3} \\
\text { groups: standard } \\
\text { formula, formula } \\
+ \text { LCPUFA } \\
(0.34 \% \mathrm{w} / \mathrm{w} \text { AA } \\
\text { and } 0.2 \% \mathrm{w} / \mathrm{w} \\
\text { DHA of total FA) } \\
\text { and human milk }\end{array}$ & Canada & $\begin{array}{l}\mathrm{N}=14 \\
\text { standard } \\
\text { formula; } \\
\mathrm{N}=16 \\
\text { formula } \\
+\mathrm{LCPUF} \\
\mathrm{A} ; \mathrm{N}=16 \\
\text { human } \\
\text { milk }\end{array}$ & $\begin{array}{l}4 \\
\text { weeks; } \\
\text { From } 14 \\
\text { days of } \\
\text { life to } 6 \\
\text { weeks }\end{array}$ & $\begin{array}{l}\text { Infants had to } \\
\text { be heathy } \\
\text { with growth } \\
\text { parameters } \\
\text { between } 10- \\
90^{\text {th }} \\
\text { percentile; } \\
\text { Low risk of } \\
\text { allergy }\end{array}$ & $\begin{array}{l}6 \text { weeks } \\
(1.5 \\
\text { month) }\end{array}$ & $\begin{array}{l}\text { Phenotyping of } \\
\text { lymphocytes, and } \\
\text { cytokine } \\
\text { production after } \\
\text { stimulation with } \\
\text { food proteins } \\
\text { (BLG and SOY) } \\
\text { and estimation of } \\
\text { lymphocytes } \\
\text { proliferation using } \\
\text { the }\left[{ }^{3} \mathrm{H}\right] \text { thymidine } \\
\text { uptake method }\end{array}$ & Yes & $\begin{array}{l}\text { 1) At } 6 \text { weeks, no difference in the proliferation } \\
\text { rate after incubation with food proteins among } \\
\text { groups was observed; } 2 \text { ) The formula+LCPUFA } \\
\text { produced more TNF- } \alpha \text { and IL- } 6 \text { with SOY and } \\
\text { IFN- } \gamma \text { with BLG vs. formula group; } 3 \text { ) } \\
\text { Formula+LCPUFA had lower } \% \text { of total CD } 20+ \\
\text { cells post-stimulation with BLG and SOY vs. HM } \\
\text { group; 4) Formula had higher IL- } 6 \text { production } \\
\text { with BLG vs. HM group }\end{array}$ \\
\hline $\begin{array}{l}\text { (Pastor et al. } \\
\text { 2006) }\end{array}$ & $\begin{array}{l}\text { Prospective, } \\
\text { obervational, open }\end{array}$ & Spain & $\begin{array}{l}\mathrm{N}=1094 \\
\mathrm{AA} \text { and }\end{array}$ & $\begin{array}{l}12 \\
\text { months }\end{array}$ & $\begin{array}{l}\text { Healthy } \\
\text { infants, born }\end{array}$ & $\begin{array}{l}12 \\
\text { months }\end{array}$ & $\begin{array}{l}7 \text { pediatrician } \\
\text { visits assessed ear }\end{array}$ & $\begin{array}{l}\text { Not } \\
\text { mentioned }\end{array}$ & $\begin{array}{l}\text { 1) Both groups had a similar growth rate } \\
\text { throughout the study; 2) Infants consuming }\end{array}$ \\
\hline
\end{tabular}

https://mc06.manuscriptcentral.com/apnm-pubs 


\begin{tabular}{|c|c|c|c|c|c|c|c|c|c|}
\hline & $\begin{array}{l}\text { label; } 2 \text { groups: } \\
\text { formula with } \\
34 \mathrm{mg} \text { AA and } \\
17 \mathrm{mg} \text { DHA vs. } \\
\text { control (no added } \\
\text { AA\DHA or low } \\
\text { amount raging } \\
\text { from: } 6-13 \mathrm{mg} \text { AA } \\
\text { and } 8-16 \mathrm{mg} \\
\text { DHA) }\end{array}$ & & $\begin{array}{l}\text { DHA; } \\
\mathrm{N}=248 \\
\text { Control }\end{array}$ & & $\begin{array}{l}\text { after } 36 \\
\text { weeks }\end{array}$ & & $\begin{array}{l}\text { infections, upper } \\
\text { respiratory } \\
\text { infection, rhinitis, } \\
\text { cough and } \\
\text { bronchiolitis/bron } \\
\text { chitis }\end{array}$ & & $\begin{array}{l}\text { formula supplemented with AA and DHA had } \\
\text { lower incidence of bronchiolitis/bronchitis at } 5 \\
\text { months, } 7 \text { months and } 9 \text { months vs. } \\
\text { unsupplemented formula; 3) There was a lower } \\
\text { occurrence of rhinitis at } 1 \text { month and a lower } \\
\text { incidence of upper airway infection at } 1 \text { month } \\
\text { and } 12 \text { months in the formula group } \\
\text { supplemented with AA and DHA vs. } \\
\text { unsupplemented formula }\end{array}$ \\
\hline $\begin{array}{l}\text { (Field et al. } \\
2000 \text { ) }\end{array}$ & $\begin{array}{l}\text { Randomized, } \\
\text { double blind, } \\
\text { controlled trial; } \underline{3} \\
\text { groups: standard } \\
\text { formula, formula } \\
\text { + LCPUFA } \\
(0.49 \% \mathrm{w} / \mathrm{w} \mathrm{AA} \\
\text { and } 0.35 \% \mathrm{w} / \mathrm{w} \\
\text { DHA of total FA) } \\
\text { and human milk } \\
\text { as a comparison } \\
\text { group }\end{array}$ & Canada & $\begin{array}{l}\mathrm{N}=12 \\
\text { standard } \\
\text { formula; } \\
\mathrm{N}=15 \\
\text { formula } \\
+\mathrm{LCPUF} \\
\mathrm{A} ; \mathrm{N}=17 \\
\text { human } \\
\text { milk } \\
(\mathrm{HM})\end{array}$ & $\begin{array}{l}4 \\
\text { weeks; } \\
\text { From } 14 \\
\text { days of } \\
\text { life to } \\
42 \text { days }\end{array}$ & $\begin{array}{l}\text { Preterm } \\
\text { infants had to } \\
\text { be medically } \\
\text { stable; No } \\
\text { infection/acut } \\
\text { e illness or } \\
\text { morbidity that } \\
\text { precludes } \\
\text { feeding by } \\
\text { mouth }\end{array}$ & $\begin{array}{l}6 \text { weeks } \\
(1.5 \\
\text { month) }\end{array}$ & $\begin{array}{l}\text { Phenotyping of } \\
\text { mononuclear } \\
\text { lymphocytes and } \\
\text { measurement of } \\
\text { soluble IL-2 } \\
\text { receptor (sIL-2R) } \\
\text { \& IL-10 } \\
\text { production after in } \\
\text { vitro stimulation } \\
\text { of lymphocytes } \\
\text { with PHA }\end{array}$ & $\begin{array}{l}\text { Not } \\
\text { mentioned }\end{array}$ & $\begin{array}{l}\text { 1) At } 42 \text { days, higher proportion of total } \\
\text { CD4+CD } 45 \text { RO+ (antigen mature) T cells in the } \\
\text { HM \& formula+LCPUFA group vs. formula; 2) } \\
\text { Lower IL-10 production in the formula vs. HM } \\
\text { group (no difference between formula+LCPUFA } \\
\text { and HM group); 3) Lower sIL-2R production in } \\
\text { the formula+LCPUFA group vs. formula (both } \\
\text { not different from HM); 4) Between } 14 \text { and } 42 \\
\text { days, the \% of CD3+CD } 4+\text { T cells and the } \% \text { of } \\
\text { CD } 20+\text { B cells increased in the HM \& } \\
\text { formula+LCPUFA group but not in the formula } \\
\text { group }\end{array}$ \\
\hline
\end{tabular}

AA, arachidonic acid; AD, atopic dermatitis; Aus, Australia; BLG, beta-lactoglobulin; ConA, Concanavalin A; DHA, docosahexaenoic acid;

EPA, eicosapentaenoic; FA, fatty acid; HDM, house dust mite; HM, human milk; IFN- $\gamma$, interferon-gamma; Ig, immunoglobulin; IL,

interleukin; LCPUFA, long chain polyunsaturated fatty acid; LPS, lipopolysaccharide; n, omega; OR, odd ratio; OVA, ovalbumin; PBMC,

peripheral blood mononuclear cell; PHA, phytohaemagglutinin; SPT, skin prick test; TGF- $\beta$, transforming growth factor-beta; TNF- $\alpha$, tumor necrosis factor-alpha; URI, upper respiratory infection. 
Table 3: Evidence from intervention studies on the impact of fish oil supplementation in the postnatal maternal diet on immune system and oral tolerance development

\begin{tabular}{|c|c|c|c|c|c|c|c|c|c|}
\hline 突 & 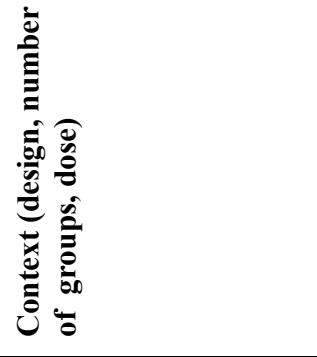 & : & 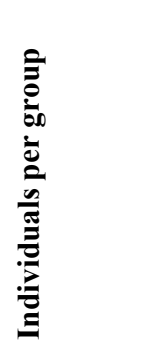 & 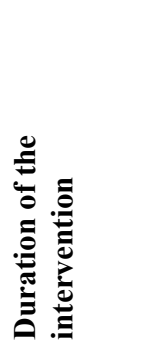 & 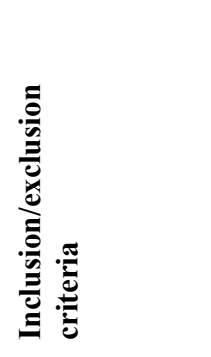 & 峁 & 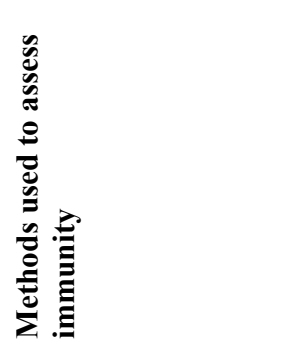 & 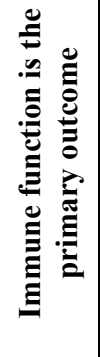 & Results \\
\hline \multicolumn{10}{|c|}{ Nutritional intervention performed strictly during the lactation period } \\
\hline $\begin{array}{l}\text { (Atwell et } \\
\text { al. 2013) } \\
* \text { Second } \\
\text { publication } \\
\text { from the } \\
\text { same study }\end{array}$ & $\begin{array}{l}\text { Randomized, double- } \\
\text { blinded, controlled trial } \\
\text { (DINO trial); } 2 \text { groups: } \\
\text { high DHA (6x500mg } \\
\text { capsules of DHA-rich } \\
\text { tuna oil (900mg } \\
\text { DHA/195mg EPA)) or } \\
\text { control (6x500mg soy } \\
\text { oil capsules) }\end{array}$ & Aus & $\begin{array}{l}\mathrm{N}=322 \\
\text { high } \\
\text { DHA; } \\
\mathrm{N}=335 \\
\text { standard } \\
\text { DHA }\end{array}$ & $\begin{array}{l}\text { Birth- } \\
\text { expected } \\
\text { delivery } \\
\text { date, } \\
\text { median } \\
\text { duration } \\
\text { of } 9.4 \\
\text { weeks }\end{array}$ & $\begin{array}{l}\text { Preterm } \\
\text { infants born } \\
\text { before } 33 \\
\text { weeks; No } \\
\text { congenital } \\
\text { abnormalities }\end{array}$ & $\begin{array}{l}\text { Age of } \\
\text { term, } 4 \\
12 \text { and } \\
18 \\
\text { months }\end{array}$ & $\begin{array}{l}\text { Parental recall of } \\
\text { hospitalisations and } \\
\text { diagnoses translated } \\
\text { into standard coding } \\
\text { diagnoses }\end{array}$ & No & $\begin{array}{l}\text { 1) No difference in the proportion of infants hospitalized } \\
\text { for lower respiratory tract conditions or in the number of } \\
\text { admissions between groups in the first } 18 \text { months of life; } \\
\text { 2) There was a trend toward a reduction in the proportion } \\
\text { of boys hospitalized for lower respiratory tract conditions } \\
\text { in the high DHA group }\end{array}$ \\
\hline $\begin{array}{l}\text { (Manley et } \\
\text { al. 2011) }\end{array}$ & $\begin{array}{l}\text { Randomized, double- } \\
\text { blinded, controlled trial } \\
\text { (DINO trial); } 2 \text { groups: } \\
\text { high DHA (6x500mg } \\
\text { capsules of DHA-rich } \\
\text { tuna oil (900mg } \\
\text { DHA/195mg EPA)) or } \\
\text { control (6x500mg soy } \\
\text { oil capsules) }\end{array}$ & Aus & $\begin{array}{l}\mathrm{N}=322 \\
\text { high } \\
\text { DHA; } \\
\mathrm{N}=335 \\
\text { control }\end{array}$ & $\begin{array}{l}\text { Birth- } \\
\text { expected } \\
\text { delivery } \\
\text { date, } \\
\text { median } \\
\text { duration } \\
\text { of } 9.4 \\
\text { weeks }\end{array}$ & $\begin{array}{l}\text { Preterm } \\
\text { infants born } \\
\text { before } 33 \\
\text { weeks; No } \\
\text { congenital } \\
\text { abnormalities }\end{array}$ & $\begin{array}{l}12 \text { and } \\
18 \\
\text { months }\end{array}$ & $\begin{array}{l}\text { Structured parental } \\
\text { interviews reporting } \\
\text { medical } \\
\text { attention/treatment } \\
\text { of hay fever, } \\
\text { eczema, asthma or } \\
\text { food allergy }\end{array}$ & No & $\begin{array}{l}\text { 1) Reduction in parental reports of hay fever in DHA } \\
\text { supplemented group at } 12 \text { and } 18 \text { months corrected age, } \\
\text { subgroup analysis showed reduction in male infants at } 12 \\
\text { months; 2) No difference in any other allergy/respiratory } \\
\text { outcome }\end{array}$ \\
\hline $\begin{array}{l}\text { (Lauritzen } \\
\text { et al. 2005) }\end{array}$ & $\begin{array}{l}\text { Randomized, double } \\
\text { blinded, placebo- } \\
\text { controlled trial; } \underline{3} \\
\text { groups: fish oil }(4.5 \mathrm{~g} \\
\text { containing } 1.5 \mathrm{~g} \mathrm{n}-3, \\
60 \% \text { DHA), control } \\
\text { (4.5g olive oil }(\mathrm{OO})) \\
\text { and reference group } \\
\text { (women with fish } \\
\text { intake in highest } \\
\text { quartile) intake (>0.8 } \\
\mathrm{g} / \mathrm{d} \mathrm{n-3)}\end{array}$ & $\begin{array}{l}\text { Denm } \\
\text { ark }\end{array}$ & $\begin{array}{l}\mathrm{N}=53 \text { fish } \\
\text { oil; } \mathrm{N}=47 \\
\mathrm{OO} \\
\mathrm{N}=53 \\
\text { reference } \\
\text { group }\end{array}$ & $\begin{array}{l}\text { First } 4 \\
\text { months of } \\
\text { breast- } \\
\text { feeding }\end{array}$ & $\begin{array}{l}\text { Women with } \\
\text { normal } \\
\text { pregnancy and } \\
\text { fish intake } \\
\text { below } \\
\text { population } \\
\text { median }(<0.4 \\
\mathrm{g} / \mathrm{d} \mathrm{n}-3) \text { and } \\
\text { in upper } \\
\text { quartile of } \\
\text { intake }(>0.8 \\
\mathrm{g} / \mathrm{d} \mathrm{n}-3)\end{array}$ & $\begin{array}{l}4 \text { and } 30 \\
\text { months } \\
(2.5 \\
\text { years })\end{array}$ & $\begin{array}{l}\text { FA composition of } \\
\text { erythrocytes at } 4 \\
\text { months and } 2.5 \\
\text { years; Plasma IgE } \\
\text { and cytokine } \\
\text { production by LPS } \\
\text { stimulated blood at } \\
2.5 \text { years; } \\
\text { Secondary } \\
\text { outcomes: parent } \\
\text { report diagnosis of } \\
\text { allergy at } 2.5 \text { years } \\
\end{array}$ & Yes & $\begin{array}{l}\text { 1) Erythrocyte n-3 (EPA and DHA) levels at } 4 \text { months was } \\
\text { higher in the fish oil group than the control group (AA } \\
\text { levels not different), but not different at } 2.5 \text { years; 2) IFN- } \\
\text { y production was } 4 \text {-fold higher in fish oil group, with } \\
\text { similar IL-10 production compared to control group at } 2.5 \\
\text { years; } 3 \text { ) IFN-y/IL-10 ratio was } 2 \text {-fold higher in fish oil } \\
\text { group and correlated to DHA and EPA content in } \\
\text { erythrocytes at } 4 \text { months; 4) At } 2.5 \text { years, percentage of } \\
\text { atopic children and plasma IgE concentrations was not } \\
\text { different between groups }\end{array}$ \\
\hline \multicolumn{10}{|c|}{ Nutritional intervention starting in the third trimester of pregnancy and maintained during the lactation period } \\
\hline
\end{tabular}




\begin{tabular}{|c|c|c|c|c|c|c|c|c|c|}
\hline $\begin{array}{l}\text { (Furuhjelm } \\
\text { et al. 2011) }\end{array}$ & $\begin{array}{l}\text { Randomized, double } \\
\text { blinded, placebo- } \\
\text { controlled trial; } 2 \\
\text { groups: } \mathrm{n}-3(1.6 \mathrm{~g} / \mathrm{d} \\
\text { EPA, } 1.1 \mathrm{~g} / \mathrm{d} \text { DHA or } \\
\text { placebo (soybean oil, } \\
2.5 \mathrm{~g} / \mathrm{d} \text { LA, } 0.28 \mathrm{~g} / \mathrm{d} \\
\text { ALA) }\end{array}$ & $\begin{array}{l}\text { Swede } \\
\mathrm{n}\end{array}$ & $\begin{array}{l}\mathrm{N}=54 \mathrm{n}- \\
3 ; \mathrm{N}=66 \\
\text { placebo }\end{array}$ & $\begin{array}{l}25 \text { weeks } \\
\text { gestation } \\
\text { to } 3.5 \\
\text { months of } \\
\text { breast- } \\
\text { feeding } \\
\text { (minimum } \\
\text { of } 15 \\
\text { weeks) }\end{array}$ & $\begin{array}{l}\text { Allergy to soy } \\
\text { or fish; } \\
\text { Anticogulants } \\
\text { or n-3 } \\
\text { supplements; } \\
\text { At least } 1 \\
\text { family } \\
\text { member with } \\
\text { history of } \\
\text { allergic } \\
\text { symptoms }\end{array}$ & $\begin{array}{l}3,12 \\
\text { and } 24 \\
\text { months }\end{array}$ & $\begin{array}{l}\text { SPT at } 6,12 \text { and } 24 \\
\text { months for egg, } \\
\text { milk, wheat, cat, } \\
\text { birch and timothy } \\
\text { grass; IgE analyzed } \\
\text { in serum at } 12 \text { and } \\
25 \text { months; FA } \\
\text { assessed by GC }\end{array}$ & Yes & $\begin{array}{l}\text { 1) Cumulative indigence of positive SPT ( } 0-24 \text { months) } \\
\text { was lower in n-3 group; 2) Symptoms of allergic disease } \\
\text { were not different; 3) IgE-mediated food reactions, } \\
\text { associated eczema and associated diseases were less } \\
\text { frequent in n-3 group; 4) Proportion of DHA and EPA was } \\
\text { higher and AA/EPA ratio was lower in maternal and infant } \\
\text { phospholipids of non-symptomatic infants, compared to } \\
\text { infants who development } 2+\text { allergic symptoms }\end{array}$ \\
\hline $\begin{array}{l}\text { (Furuhjelm } \\
\text { et al. 2011) } \\
\text { *Second } \\
\text { publication } \\
\text { from the } \\
\text { above study }\end{array}$ & $\begin{array}{l}\text { Randomized, double } \\
\text { blinded, placebo- } \\
\text { controlled trial; } 2 \\
\text { groups: } \mathrm{n}-3(1.6 \mathrm{~g} / \mathrm{d} \\
\text { EPA, } 1.1 \mathrm{~g} / \mathrm{d} \text { DHA or } \\
\text { placebo }(\text { soybean oil, } \\
2.5 \mathrm{~g} / \mathrm{d} \text { LA, } 0.28 \mathrm{~g} / \mathrm{d} \\
\text { ALA) }\end{array}$ & $\begin{array}{l}\text { Swede } \\
\mathrm{n}\end{array}$ & $\begin{array}{l}\mathrm{N}=54 \mathrm{n}- \\
3 ; \mathrm{N}=66 \\
\text { placebo }\end{array}$ & $\begin{array}{l}25 \text { wks } \\
\text { gestation } \\
\text { to } 3.5 \\
\text { months of } \\
\text { breast- } \\
\text { feeding } \\
\text { (minimum } \\
\text { of } 15 \\
\text { weeks) }\end{array}$ & $\begin{array}{l}\text { Allergy to soy } \\
\text { or fish; } \\
\text { Anticogulants } \\
\text { or n-3 } \\
\text { supplements; } \\
\text { At least } 1 \\
\text { family } \\
\text { member with } \\
\text { history of } \\
\text { allergic } \\
\text { symptoms }\end{array}$ & $\begin{array}{l}3,12 \\
\text { and } 24 \\
\text { months }\end{array}$ & $\begin{array}{l}\text { Plasma used to } \\
\text { assess chemokines } \\
\text { by ELISA or } \\
\text { Luminex assay }\end{array}$ & Yes & $\begin{array}{l}\text { 1) High Th2-associated CC-chemokine ligand } 17 \text { (CCL17) } \\
\text { levels were associated with infant allergic disease; } 2 \text { ) In } \\
\text { infants without history of allergic disease, n-3 } \\
\text { supplementation resulted in lower CCL17/CXC- } \\
\text { chemokine ligand } 11 \text { (CXCL11) (Th2/Th1) ratio; 3) In } \\
\text { non-allergic infants, n-3 supplementation was associated } \\
\text { with higher Th1 CXCL11 and increased IgG titers to } \\
\text { diphtheria and tetanus toxins }\end{array}$ \\
\hline $\begin{array}{l}\text { (Furuhjelm } \\
\text { et al. 2009) } \\
\text { *Third } \\
\text { publication } \\
\text { from the } \\
\text { above study }\end{array}$ & $\begin{array}{l}\text { Randomized, double } \\
\text { blinded, placebo- } \\
\text { controlled trial; } 2 \\
\text { groups: } \mathrm{n}-3(1.6 \mathrm{~g} / \mathrm{d} \\
\text { EPA, } 1.1 \mathrm{~g} / \mathrm{d} \text { DHA or } \\
\text { placebo (soybean oil, } \\
2.5 \mathrm{~g} / \mathrm{d} \text { LA, } 0.28 \mathrm{~g} / \mathrm{d} \\
\text { ALA) }\end{array}$ & $\begin{array}{l}\text { Swede } \\
\mathrm{n}\end{array}$ & $\begin{array}{l}\mathrm{N}=54 \mathrm{n}- \\
3 ; \mathrm{N}=66 \\
\text { placebo }\end{array}$ & $\begin{array}{l}25 \text { wks } \\
\text { gestation } \\
\text { to } 3.5 \\
\text { months of } \\
\text { breast- } \\
\text { feeding } \\
\text { (minimum } \\
\text { of } 15 \\
\text { weeks) }\end{array}$ & $\begin{array}{l}\text { Allergy to soy } \\
\text { or fish; } \\
\text { Anticogulants } \\
\text { or n-3 } \\
\text { supplements; } \\
\text { At least } 1 \\
\text { family } \\
\text { member with } \\
\text { history of } \\
\text { allergic } \\
\text { symptoms }\end{array}$ & $\begin{array}{l}3,12 \\
\text { and } 24 \\
\text { months }\end{array}$ & $\begin{array}{l}\text { SPT at } 6,12 \text { and } 24 \\
\text { months for egg, } \\
\text { milk, wheat, cat, } \\
\text { birch and timothy } \\
\text { grass; IgE analyzed } \\
\text { in serum at } 12 \text { and } \\
25 \text { months }\end{array}$ & Yes & $\begin{array}{l}\text { 1) The period of prevalence of positive egg SPT up to } 12 \\
\text { months was lower in n-3 group; 2) Incidence of IgE- } \\
\text { associated eczema was lower in the n-3 group; 3) Food } \\
\text { allergy during the first year of life was significantly less } \\
\text { frequent in the n-3 group; 4) Risk of development a } \\
\text { positive SPT to egg or IgE-associated eczema during the } \\
\text { first year of life was } 3-4 \text { times greater in placebo group }\end{array}$ \\
\hline
\end{tabular}

AA, arachidonic acid; ALA, $\alpha$-linolenic acid; Aus, Australia; CCL, CC-chemokine ligand; CXCL, chemokine (C-X-C motif) ligand; DHA,

docosahexaenoic acid; EPA, eicosapentaenoic; FA, fatty acid; IFN- $\gamma$, interferon-gamma; Ig, immunoglobulin ; IL, interleukin; LA, linoleic acid; LPS, lipopolysaccharide; n, omega; SPT, skin prick test; 